\title{
Syntax in interaction
}

\section{Form and function of yes/no interrogatives in spoken standard French ${ }^{\star}$}

\author{
Maj-Britt Mosegaard Hansen \\ University of Copenhagen
}

This paper investigates the correlation between the form and function of yes/no interrogatives in spoken French. The standard language possesses three ways of constructing such interrogatives: verb-clitic inversion; prefixation of a declarative sentence with the interrogative particle est-ce que; and a rising intonation pattern superposed on a declarative structure. The choice between the three has traditionally been described in terms of register differences. This paper argues, however, that the three constructions differ not only on the pragmatic level, but also on the semantic level, and that the choice between them can be explained, and largely predicted, in terms of three interactional parameters, namely the accessibility of the information contained in the interrogative; participation structure; and considerations of 'face'.

\section{Introduction}

It is generally recognized that contemporary standard French has three ways of constructing yes/no interrogatives: $:^{1,2}$

1. Use of ('complex') inversion, i.e. verb-subject clitic word order, with the possibility of inserting a coreferential NP before the verb if the latter is in the third person (abbreviated $\mathrm{V}-\mathrm{Cl}$ in the following), as in (1):

(1) (Pierre $_{i}$ )va-t-il venir ? $^{3}$

Lit: '(Pierre) will he come?'

2. Use of a declarative sentence prefaced with the grammaticalized particle est-ce que (lit.: 'is it that') - itself an inverted structure - (abbreviated ESV), as in (2): 
(2) Est-ce que Pierre/il va venir?

Lit: 'Is it that Pierre/he will come?'

3. Use of a declarative sentence structure which in the spoken language is marked as an interrogative by rising intonation, and in writing by the use of a question mark (abbreviated SV), as in (3):

(3) Pierre/Il va venir?

Lit.: 'Pierre/He will come?'

Although it is acknowledged that there are significant differences in the frequency of occurrence of these three constructions in different contexts, they are often regarded as synonymous, especially in language-teaching situations, the difference between them being considered mainly one of register, such that the more formal the speech event, the more likely it is that (complex) inversion will be used, whereas plain declarative word order is more likely to be used for informal communication. Indeed, while $\mathrm{V}$-Cl is practically absent in spontaneous speech, it is alive and well in writing, and conversely, SV is overwhelmingly favored in speech, but is relatively infrequent in writing.

However, although I have no doubt that register is to some extent a relevant parameter, such an account is not without problems. For one thing, it does not explain the existence of the est-ce que-variant, which - although it has frequently been evaluated as sub-standard by purists (cf. Grevisse 1988:650) actually seems fairly neutral with respect to register. To account for this form, politeness distinctions are sometimes invoked, but ESV has been varyingly described both as less brusque, and therefore more polite than the alternatives (Foulet 1921:313; Coveney 1996:247) and as more insistent (Fromaigeat 1938:34f; Terry 1970:103f), and consequently, often less polite. Clearly, in so far as either description does in fact seem applicable to at least some examples, it is reasonable to think that the degree of politeness conveyed by ESV is likely to be an epiphenomenon of some other semantic or pragmatic parameter(s) which determine(s) the use of the construction.

Secondly, two or even three of these forms may, as a matter of fact, be used by one and the same speaker/writer during one and the same communicative event - often in close proximity to each other, cf. the following example: 
(4) T1 A. ...mais e: comme / que si par exemple ta mère m'avait au bout du fil T2 B. oui

T3 A. bon, j'appelle, c'est elle qui décroche, eh ben elle aurait l'impression que je suis une petite fille

T4 B. pourquoi / t'es timide? t'\&as une voix timide?

T5 A. \& non

T6 A. ouais c'est ça,, je fais allô e: bonjour, e:, je suis bien chez la famille e (h) Carretta? alors elle me dit ben: oui, je lui ferais, pourrai(s)-je parler à Murielle s'il vous plaît? (h) [B laughs] comme ça, (h) et encore bon là c'est pas évident mais quand je / quand j'ai / j'ai la personne au bout du fil je parle toujours comme ça

T7 B. mais sinon est-ce que t'es timide? quঊand tu connais pas les gens? T8 A. \& moi? $(\mathrm{CT}, 7)^{4}$

'A. but er like / if for instance your mother were talking to me on the phone

B. yes

A. well, I'm calling, she answers, well, she'd get the impression that I was a little girl

B. why / are you shy? do \& you have a shy voice?

A. \& no

A. yeah that's it, I go hello er hello, er, is this the Carretta er residence? and then she says well yes I'd go, could I speak to Murielle please? (h) [B laughs] like that, (h) and yet well there it's not obvious but when I / when I / I have somebody on the phone I always talk like that B. but otherwise are you shy? wh\&en you don't know people? A. \& me?'

This suggests that the three forms may not be entirely synonymous, and that accounting for their use in terms of register variation may be too simplistic.

Thirdly, it would appear that certain specific types of interrogative contexts exclude at least one, and sometimes two, of the alternative structures. ${ }^{5}$ For instance, in so-called echo-questions, only the SV-structure seems acceptable :

(5) A: mais ça on n'y est pas allés là non

B: vous n'y êtes pas allés? (VE, 14)

${ }^{*} n^{\prime} y$ êtes-vous pas allés?

*est-ce que vous n'y êtes pas allés?

(A: but that we didn't go there no

B: you didn't go there?) 
- and, conversely, a self-addressed question of the type in (6) seems to exclude SV:

(6) A: et donc e en fait pour revenir au mariage

B: $m, m m$

A. puisque c'était ça le point de départ, on vou/ on voulait savoir ce que vous en pensiez et tout e donce

B. oh voyons est-ce que je suis libre (AF, 4a)

oh voyons suis-je libre?

*oh voyons je suis libre?

(A: and so er in fact to come back to the wedding

B: $\mathrm{m}, \mathrm{mm}$

A: since that was the starting point, we wan/ we wanted to know how you felt about it and everything er so er

B: oh let's see now will I be free)

\section{Previous studies}

To date, there are relatively few studies of the form-function correlation in yes/no interrogatives as used in adult speech, mainly Fromaigeat (1938), Pohl (1965), Terry (1970), Behnstedt (1973), Ashby (1977), Fontaney (1991), and Coveney (1996), although remarks on semantic and/or pragmatic contrasts between the forms can be found elsewhere, for instance in Foulet (1921), Damourette \& Pichon (1911-1934), and Rémi-Giraud (1991). ${ }^{6}$ The principal studies mentioned are all empirically based, but differ in both scope and methodology, although all, with the exception of Fontaney (op.cit.), are explicitly quantitative.

The studies mentioned contain not only useful data, but also careful and highly suggestive analyses. Nevertheless, in most cases, the data on which they are based are either not authentic spoken data at all, or else they do not represent a range of speech styles. Moreover, no very clear form-function correlations emerge from them.

In two of the older studies (Fromaigeat 1938, Terry 1970), the data base consists of fictional representations of informal spoken dialogue, mainly in the form of contemporary boulevard plays. Pohl (1965) is a very small-scale study, the spoken-language part of which includes the language of only two elderly informants, the data having been written down by the researcher rather than recorded on tape. Behnstedt (1973), Ashby (1977) and Coveney (1996) all have 
a sociolinguistic focus, but Behnstedt's study is to a large extent based on questionnaire data, all his attested examples being obtained from radio broadcasts, and the studies by Ashby and Coveney are based on one form of interaction only, namely sociolinguistic interviews. The only study to be based on a variety of interaction types is that of Fontaney (1991), whose interactional orientation is also very similar to mine. She is, however, primarily concerned with the correlation between pragmatic function and intonation, rather than syntax.

It seems to me, therefore, that the study of syntax-function correlations in French interrogatives might profit from a consideration of more varied interactional data, which is what the present paper attempts to offer. However, not only a different type of data, but also a different methodology from those used in most of the previous studies will be proposed here, namely one that systematically takes into account such interactional factors as conversational structure, face work, participant structure and the participants' presumed knowledge of the events being discussed. ${ }^{7}$

\section{Hypothesis of the present study}

The hypothesis of the present paper is that the three interrogative forms are in fact not synonymous, and that their differential use can be explained with reference to interactional factors. A starting point of the investigation is the assumption made in various contemporary grammatical theories, for instance Construction Grammar (e.g. Fillmore, Kay \& O’Connor 1988) and Cognitive Grammar (Langacker 1987:81ff), that syntactic structures convey meaning in and of themselves, independently of the specific lexical items which enter into particular instantiations of them. Thus, I will argue that the differential use of the $\mathrm{V}-\mathrm{Cl}, \mathrm{ESV}$ and SV structures is at a very basic level related to the specifics of their form.

First, on a very general semantic/pragmatic level, I hypothesize that our abstract prototypical representation of yes/no questions ${ }^{8}$ is characterized by the following two properties:

1. The speaker is signaling to the hearer that it is relevant for someone (prototypically, but not necessarily the speaker herself) to wonder about the validity of the proposition expressed.

2. The speaker is appealing to the hearer for a reaction to that proposition. 
These two properties are logically independent of one another. Thus, a selfaddressed question such as that in (7), does not appeal to the hearer for an evaluation of the proposition, and conversely, a declarative expressing an indirect act of blaming such as (8) will, in most circumstances, be uttered with an expectation that the hearer will express either agreement or (preferably) disagreement (cf. Heritage 1984:269), but it cannot be said to signal that the validity of the proposition is somehow in doubt:

(7) ...c'est curieux quand on a fait le:, enfin quand on a parlé de la construction des pyramides et tout, (h) c'est e la la la la guide qu'on avait a bien DIT nous a bien fait remarquer que: ça avait été construit mais PAS par des esCLAVES, il n'y avait PAS d'esclaves alors je ne sais pas e:, (h) elle, est-ce que c'est elle qui le disait parce qu'elle voulai:t $e:$, , montrer que: il n'y avait pas d'esclavage en Egypte j'en sais rien, mai:s (VE, 40)

'...it's funny when we did the, well when we discussed the construction of the pyramids and everything, (h) it's er the the the the guide that we had DID say did tell us that they had been constructed but NOT by SLAves, there were NO slaves so I don't know er, (h) she, was it just something she said because she wanted to er, show that there was no slavery in Egypt I don't know, but'

(8) A. tu sais très bien qu'on t'aurait changé,, \& Marie si

B. \& non non non alors là j'en suis sûre que tu te plantes... (CV, 29)

'A. you know perfectly well they'd have given you something else to do \& Marie yes

B. \& no no no really I'm sure you're wrong about that...'

Clearly, however, the properties will be pragmatically linked in a great many contexts: Thus, if a speaker interacting with a cooperatively inclined interlocutor mentions that it is relevant to wonder about a certain proposition that the addressee can reasonably be expected to have a qualified opinion about, then her reason for doing so will, in many cases, be the hope that the addressee might settle the matter. And conversely, a speaker who appeals to her interlocutor for a reaction to a given proposition will in many cases be in doubt about the status of that proposition.

Hence, the two properties taken together may be said to characterize prototypical instances of what we understand as yes/no questions. Thus, the above characterization centrally includes requests for information: here the speaker herself is wondering about the validity of the proposition, and is asking the hearer to supply the relevant polarity. 
However, the present formulation allows for the existence of a number of utterances which to some extent deviate from the pattern of requests for information. For instance, it includes examination questions, where the speaker can (in most cases at least) be assumed to know the answer beforehand. They nevertheless qualify as questions because this answer is not self-evidently a matter of common knowledge in the community (in which case there would be strictly speaking no point in checking the hearer's knowledge of it), and is therefore something that someone could be expected to wonder about.

More controversially, perhaps, so-called indirect offers (9), and indirect requests for permission (10) or action (11), will also qualify as questions on this view:

(9) Voulez-vous que je vous accompagne?

'Would you like me to accompany you?'

(10) Maman, je peux aller jouer avec Benjamin après le dîner?

'Mom, can I go play with Benjamin after dinner?'

(11) Pourriez-vous me passer le sel, s'il vous plaît?

'Could you pass the salt, please?'

I do not find this result troublesome. Indirect offers and requests for permission seem to me to resemble requests for information to quite a large extent, in as much as the speaker is in both cases wondering about the validity of the proposition, and is in both cases requesting no more than a prototypically verbal response from the hearer, any subsequent action usually being on the speaker's part. As far as indirect requests for action are concerned, even favorable responses typically include not only the action in question, but also some sort of verbal confirmation of the proposition expressed in the request, e.g. Yes, Sure, or the like, while unfavorable responses will almost invariably consist in a negative evaluation of the proposition, often accompanied by reasons justifying that evaluation. Moreover, on a fundamental level, indirect speech acts in the interrogative form can be seen quite generally as being questions, namely questions about hearer-based felicity conditions attached to the speech act which they indirectly seek to perform (cf. Gordon \& Lakoff 1975).

Because of their independence, the hypothesized properties also allow for various other more marginal (or less prototypical) question types. For instance,the above-mentioned self-addressed questions, where the speaker may wonder, but no reaction from the hearer is elicited. Or rhetorical questions such as (12) and (13): 
(12) Ai-je jamais refusé de t’aider?

'Have I ever refused to help you?'

(13) A. Tu crois que Luc se marie avec Arlette parce qu'elle est riche?

B. Le Pape est-il catholique?

'A. Do you think Luc is marrying Arlette because she's rich?

B. Is the Pope Catholic?'

Again, in such utterances, no response from the hearer is solicited (although it may in many cases be forthcoming nevertheless, cf. Kerbrat-Orecchioni 1991: 103). Moreover, the speaker herself is not wondering about the validity of the proposition. Rather, such questions can, according to Anscombre \& Ducrot (1983, ch. 5), be analyzed as polyphonic, i.e. as echoing some actual, or more probably potential, utterance by someone other than the present speaker ( frequently the individual to whom this potential utterance is attributed will be the present hearer, in which case the interrogative will be not only polyphonic, but diaphonic [cf. Roulet et al. 1987:70]).

That is to say, a rhetorical question like (12) conversationally implicates (cf. Grice 1975) I have never refused to help you, but will typically be uttered in a context where the speaker feels she is the object of some sort of reproach on the hearer's part. What is attributed to the hearer is the underlying proposition I have refused to help you in the past, and the speaker is suggesting that the hearer stop to wonder about the validity of this proposition. In a similar vein, B's question in (13) conversationally implicates Yes, Luc is marrying Arlette because she is rich, but above and beyond that implicature, it also conveys the assumption that if A can have any doubts about Luc's reasons for marrying Arlette, then he is equally likely to have doubts about the Pope's religious affiliation, i.e. although the question is uttered by the speaker, it is echoically attributed to the hearer. ${ }^{9}$

Conversely, one finds evaluative utterances including an interrogative tag such as (14), where the hearer is clearly being appealed to for a reaction, but where it would not be meaningful to claim that the speaker or anyone else is wondering about the proposition:

(14) [In front of a painting in a museum] C'est beau, n'est-ce pas? 'It's beautiful, isn't it?'

There are a number of additional pragmatic uses of yes/no interrogatives, some of which will be mentioned in the empirical part of this paper. The main point in this section is merely to support my characterization of yes/no questions as 
prototypically involving the two properties of wondering about a proposition and appealing to one's addressee.

Now, the central hypothesis of the present paper is that French has in fact grammaticalized these two question properties in different structures, $\mathrm{V}-\mathrm{Cl}$ and ESV codifying the first property, and SV the second. This, I hypothesize, is directly linked to the syntactic properties of the constructions: The $\mathrm{V}-\mathrm{Cl}$ construction fronts the finite verb (if there is no subject NP present in the clause) or at least highlights it by framing it between two subject elements, ${ }^{10}$ the border between the verb and the subject NP being additionally marked by an intonational break - however small. This construction thus focalizes the very process denoted by the clause.

The ESV construction, in a similar vein, fronts the existential être of the by now frozen question particle est-ce que, thus focalizing the reality of the stateof-affairs denoted by the main proposition (cf. Damourette \& Pichon 1911-1934:327; Rémi-Giraud 1991:51). ESV is thus a more emphatic interrogative structure than $\mathrm{V}-\mathrm{Cl}$.

This should not be taken as a claim that present-day uses of est-ce que retain the literal interpretation they presumably had when the form first appeared in the 16th century (Foulet 1921:265): the fact that est is invariably in the present tense no matter what the tense of the main verb may be, and that the sequence is frequently phonologically reduced to [ $\varepsilon \mathrm{sk}]$, [sk], and even a mere [s], strongly indicates that it has been grammaticalized as an interrogative particle. However, as Hopper (1991:22) points out, it is quite common for grammaticalized elements to retain some of the meaning of the source construction, a phenomenon known as 'persistence'. Moreover, the particle est-ce que has no other function in contemporary French than to mark interrogation, contrary to inversion and rising intonation, which both have other uses. Introducing a clause by such a 'pure' interrogation marker therefore serves only to highlight the doubt thrown on the process denoted by the core proposition.

If this is correct, $\mathrm{V}-\mathrm{Cl}$ and ESV may, although far less frequently used than SV in the spoken language at least (a fact which I will seek to explain below), in some sense be considered to be the 'true' interrogative structures, namely those which display "grammaticalization of the feature of doubt" (Lyons 1977:754). By virtue of their form alone, however, they do not contain an explicit appeal to the interlocutor, although such an appeal may often be inferred from the context in which these forms appear.

In the SV construction, on the other hand, the syntactic structure is that of a declarative sentence, i.e. a fundamentally assertoric structure. ${ }^{11}$ However, the 
rising intonation functions as a kind of 'try-marker' (Sacks \& Schegloff 1979), signaling openness and uncertainty/incompletion (Rémi-Giraud 1991:45), hence the perceived appeal to the interlocutor.

It is important that the rising intonation pattern of SV be seen as having precisely this broader and more vaguely defined function, rather than the function of signaling interrogation as such, because as a number of scholars (cf. Fontaney 1991 and references therein) have noted, there is in fact no such thing as an unambiguous 'question intonation'. That is to say, utterances displaying falling or level intonation may nevertheless function quite adequately as questions, and utterances with rising intonation may have non-question functions. Thus, for instance, the following ESV example has falling intonation, but functions quite unambiguously as a request for information:

(15) A. ...voilà est-ce que ça se retrouve ça

B. pas tellement... (VE, 35)

'A. ...right do you find that

B. not really...'

Conversely, the utterance in (16) has rising intonation, but can hardly be understood as a question, even of a non-prototypical kind. In its context, it can, however, be understood as appealing to the interlocutor for some sort of reaction:

(16) ...parce que je crois qu'il faut s'y prendre assez rapidement? en fait?... (AF, 4a)

'...because I think we have to act pretty quickly actually...'

The SV interrogative, then, does not grammaticalize the 'feature of doubt' as such - if relevant, this must be inferred from the context, and these interrogatives are therefore more assertive in force than either $\mathrm{V}-\mathrm{Cl}$ or ESV.

It should not be inferred from this that SV is used only for questions expecting a positive answer. The structure seems to be largely neutral in orientation, inasmuch as explicit markers are needed if one wants to lend a specifically positive (17) or negative (18) orientation to an SV interrogative:

(17) A. Je ne savais pas qu'Antoine avait été muté à Genève

B. Il ne te l'avait pas dit?

'A. I didn't know that Antoine had been transferred to Geneva

B. Didn't he tell you?'

(18) Antoine a vraiment demandé à être muté à Genève?

'Did Antoine really ask to be transferred to Geneva?' 
On the other hand, the SV structure does seem to lack the negative orientation displayed by both the $\mathrm{V}-\mathrm{Cl}$ and the ESV structures in argumentative contexts (cf. Anscombre \& Ducrot 1983, ch. 5):

(19) C'est un peu idiot d'abandonner ton poste. Est-ce que tu pourras trouver mieux à Lyon? (op.cit., 117)

'It's a bit stupid to leave your job. Can you find something better in Lyons?'

(19') C'est un peu idiot d'abandonner ton poste. Pourras-tu trouver mieux à Lyon?

(19") \#C'est un peu idiot d'abandonner ton poste. Tu pourras trouver mieux à Lyon $?^{12}$

(20) Il fait beau aujourd'hui, mais fera-t-il beau demain? (op.cit., 118) 'The weather is nice today, but will it be nice tomorrow?'

$\left(20^{\prime}\right)$ Il fait beau aujourd'hui, mais est-ce qu'il fera beau demain?

$\left(20^{\prime \prime}\right)$ *?Il fait beau aujourd'hui, mais il fera beau demain?

The interrogatives in (19)-(19') and (20)-(20') all implicate that the truth of the underlying proposition is uncertain, and an expression of uncertainty with respect to a given proposition generally has the same argumentative direction as the negation of that proposition (Anscombre \& Ducrot op.cit.: 132). Thus, in (19) $-\left(19^{\prime}\right)$, the interrogatives function as arguments in favor of the conclusion stated in the preceding declarative, It's a bit stupid to leave your job, while in (20) $-\left(20^{\prime}\right)$, the interrogative conjuncts function as counter-arguments to the declarative first conjunct, implicating a conclusion along the lines of Let's not plan a picnic for tomorrow. In (19"), however, no such negation of the proposition is implicated ( - at least a very special intonation pattern would be needed to bring it out), hence the oddity of the sequence, and (20") is quite simply impossible without a very marked intonation pattern and a significant break after mais. ${ }^{13}$

As in the rhetorical questions (12)-(13) above, $\mathrm{V}-\mathrm{Cl}$ and ESV in these examples have a diaphonic or at least polyphonic quality, as already observed by Anscombre \& Ducrot (op.cit., 132f). That is, the underlying positive proposition is attributed to someone other than the present speaker, most probably the hearer, whereas the doubt expressed by the interrogative structure is felt by the speaker, and - it is implicated - ought to be felt by the hearer as well.

This is not the case in $\left(19^{\prime \prime}\right)$ and $\left(20^{\prime \prime}\right)$ where the speaker takes responsibility for presenting a proposition for the hearer's subsequent evaluation. 


\section{Analytical framework and predictions of the present study}

The above hypothesis - that $\mathrm{V}-\mathrm{Cl}$ and ESV code the first of the two question properties (and that utterances of $\mathrm{V}-\mathrm{Cl}$ or ESV structures may, in context, pragmatically implicate the second property), while SV codes the second property (but that utterances of SV interrogatives may, in context, pragmatically implicate the first property) - leads to certain predictions with respect to the interactional features of actual interrogatives.

\subsection{Accessibility of information and event typology}

Labov \& Fanshel (1977: 100) classify statements made in interaction in terms of the knowledge which different interactants may be assumed to have of the events denoted by the statements. The typology they establish is as follows:

A-events: Known to A but not to B.

B-events: Known to B, but not to A.

AB-events: Known to both A and B.

O-events: Known to everyone present.

D-events: Known to be disputable. (Labov \& Fanshel, loc.cit.)

A should be understood as the speaker, and B as the hearer. Typical A-events will "concern [the speaker's] emotions, his daily experience in other contexts, elements in his past biography, and so on." (ibid.), while B-events will be similar events in the hearer's life. Moreover, "[i]f there is any doubt about the status of a particular event, it automatically falls into the class of D-events" (ibid.). The authors also state that:

If A makes a statement about a B-event, then it is heard as a request for confirmation (ibid.)

In the analyses below, this typology of events will be applied to the propositions underlying the interrogatives in the data base. The prediction is that, due to the declarative syntax of SV interrogatives and the try-marking nature of their intonation, questions featuring SV will tend to be questions about B-events, while questions using $\mathrm{V}-\mathrm{Cl}$ and $\mathrm{ESV}$ will tend to be about other types of events. 
Secondly, I have hypothesized that when asking a question, the speaker is communicating only that it is relevant for someone to wonder about the validity of the proposition. Whether or not that someone is the speaker herself is in each case to be determined by the context. I have already illustrated this with the polyphonic quality of rhetorical and argumentative questions, for the coding of which V-Cl and ESV appear better suited than SV.

Rather than adopt Ducrot's (1984: ch. VIII) theory of polyphony as such, I prefer, however, to base my analysis on Goffman's (1981) theory of participation structure, or 'footing. Both theories represent important deconstructions of the traditionally taken-for-granted notions of 'speaker' and 'hearer', but where Ducrot's theory poses polyphony as an inherent feature of certain types of utterances, Goffman sees the matter entirely in interactional terms.

Briefly, the individual who physically makes an utterance may not be responsible for either its form, its content, or both. Conversely, is it entirely possible to hear and understand an utterance without being either the intended recipient of that utterance, a ratified participant in the interaction, or both. Thus, at the production end of utterances, Goffman (op.cit.) distinguishes between an 'animator' (i.e. the individual producing the speech sounds), an 'author' (i.e. the individual who is responsible for the form of the utterance), and a 'principal' (i.e. the individual responsible for the content of the utterance), while at the reception end, he distinguishes two types of ratified participants ('addressee' and 'audience') and two types of non-ratified participants ('overhearers' and 'eavesdroppers').

To take a relatively straightforward example of a complex production format, a politician giving a speech which someone else has written for her, will clearly be the animator of that speech. Usually, she will also to at least some extent be its principal, but she will not be its author, and the principalship may be shared with one or more other persons. A television news interview will exemplify a complex reception format: here the interviewer will be the immediate addressed recipient of the interviewee's answers, while the viewers will constitute a ratified audience, who will also in an important sense be the true recipients. And, if the interview is filmed in a public place, anyone happening to be within hearing range will qualify as either a bystander or an eavesdropper, depending on whether the official participants are aware of his presence or not.

Now, my prediction with respect to French interrogatives is that the more complex the participation structure displayed by a given utterance, the more likely it is that the utterance will be to be expressed by either V-Cl or ESV, partly because of the unspecified identity of the individual(s) who are assumed to be 
wondering about the underlying proposition, and partly because these structures do not explicitly appeal to the co-present hearer for a reaction. Utterances displaying a simple participation structure, on the other hand, will be more likely to be expressed by SV.

Not all possible types of structural complexities will be equally relevant to the present study, however. The most important types are those where the current speaker is not the principal of the utterance, and those where the ostensible illocutionary force of a particular interrogative utterance is clearly not directed at the ratified co-present hearer to whom the discourse as a whole is addressed. Thus, quoted interrogatives, for instance, will be feature a relevant kind of complexity. On the other hand, interrogative tokens in which certain production or reception roles happen to be filled by one or more other individuals in addition to the current speaker or ratified co-present hearer are analyzed as having a simple production format as far as the predictions for interrogative structure are concerned.

\subsection{Face work}

Finally, the notion of politeness or 'face work' (Goffman 1967, Brown \& Levinson 1987) is also relevant to the analysis of interrogatives, in as much as Goody (1978) analyzes questions as fundamentally Janus-faced, having both a control and a deference function. These functions are present simultaneously in all questions, but in differing proportions, such that one or the other will usually predominate.

The control function stems in part from the fact that questions are prototypical first parts of adjacency pairs, and as such, 'sequentially implicative' (Heritage 1984:245). That is, asking a question provides a way for one person to compel another to perform a specific next action, namely to speak to her on a subject of her choosing. Secondly, by answering a question, one assumes responsibility for the truth of the proposition expressed in that answer.

The deference function of questions, on the other hand, comes about because questions typically at least imply ignorance. By asking a question, one therefore defers to the addressee's knowledge, and to his right to take responsibility for the truth of a particular proposition.

Now, in Brown \& Levinson's (1987) elaboration of Goffman's theory of face work, all members of a given community are seen as endowed with both a positive and a negative face. The former refers to members' self-image, including their desire to be appreciated, and to have their values appreciated by 
others. Negative face, on the other hand, refers to their equally strong desire to be free agents, i.e. to be able to do as they please without having anything imposed on them by others. A large variety of social acts are seen as implicitly or explicitly threatening, usually to the hearer's positive or negative face, but also at times to one or both of the speaker's own faces. Such acts therefore occasion the use of redressive strategies (i.e. politeness strategies), which, depending on the relationship between interlocutors and on how serious the face-threat is perceived to be in the circumstances, can be directed either to positive or to negative face.

Thus, a request, for instance, will pose a threat to the hearer's negative face, because it counts as an attempt to impose a particular course of action on him, which he could not have been expected to undertake of his own accord. At the same time, but typically less prominently, it will also pose a threat to the speaker's own faces, her negative face by prospectively putting her in debt to the hearer, and her positive face because having to make a request implies her powerlessness to bring about the desired state of affairs on her own.

Within this framework, a great many questions (including, prominently, those which can be analyzed as some form of requests, be it for information, for permission or for action) are inherently face-theatening for both speaker and hearer. They will pose a threat mainly to the hearer's face in contexts where they primarily have control function, and mainly to the speaker's own face in contexts where they primarily have deference function. We may assume that the control function will be strongest when an individual of superior social status addresses an inferior, whereas the deference function will be strongest when an inferior addresses a superior.

According to my hypothesis, $\mathrm{V}-\mathrm{Cl}$ and ESV should be best suited for the deference function, because they explicitly code uncertainty with respect to the underlying proposition, whereas any appeal to the addressee is pragmatically determined. SV, on the other hand, is less well suited for deference because it explicitly codes an appeal to the addressee, but makes the function of expressing uncertainty context-dependent. I would therefore predict that the ratio of SV interrogatives will increase in contexts where the interlocutors are social equals and/or relatively intimate, whereas the ratio of $\mathrm{V}-\mathrm{Cl}$ and ESV will increase in contexts where the interlocutors are socially unequal and/or distant.

Now, it should be noted that the three parameters mentioned may not invariably converge on the choice of one particular form. This means that the speaker will have to subjectively estimate the importance of the individual 
parameters in the given communicative context and choose the form that appears to be the 'best compromise'.

Moreover, certain formal factors may interfere, and act as a filter on an otherwise possible construction. For one thing, a number of researchers have noted that for a majority of verbs, the $\mathrm{V}-\mathrm{Cl}$ construction gives phonetically undesirable results in the 1st person singular present tense (e.g. Coveney 1996: 190) and is therefore to be avoided. Secondly, ESV is not entirely felicitous together with negation, probably because it seems slightly odd to wonder about the reality of a negated proposition, so although the two are not mutually exclusive, their co-occurrence is relatively rare (Behnstedt 1973:196). Thirdly, although it can in principle have any of the three forms, the second clause of an alternative interrogative is on the whole constrained to have the same form as the first clause (op.cit.: 198). And fourthly, very long sentences tend to be infelicitous with SV, presumably because the rising intonation pattern is difficult to sustain over a long stretch of speech.

\subsection{Specific properties of ESV}

Finally, there exists a final parameter, which has to do, not with the postulated abstract question properties, but with the already mentioned fact that ESV appears, due to its particular form, to be a more emphatically interrogative construction than either SV or V-Cl.

Due to this emphatic character, ESV may for one thing imply a stronger degree of doubt about the proposition than V-Cl. Thus, Fromaigeat (1938:46) notes that the unmarked way of inquiring about someone's health is by using SV: Vous allez bien? ('Are you well?'). The $\mathrm{V}-\mathrm{Cl}$ construction Allez-vous bien ? seems, he says, to imply that the speaker is not very interested in getting an answer, while ESV, Est-ce que vous allez bien?, would only be felicitously used if the speaker knew that the hearer had been ill.

Furthermore, because of its emphatic character, ESV will be well suited for marking the negotiation of a new phase in the interaction, for instance a change of topic or action sequence. This function of ESV interrogatives has been noted by Söll (1971).

\section{An interaction-based analysis}


In this section, I will first describe the data base which has provided the empirical foundation for the present investigation, which is primarily a study of yes/no interrogatives in spoken standard French. Subsequently, the corpus will be analyzed to see if the predictions in Section 4 are borne out.

\subsection{Description of the corpus}

My analysis is based mainly on a corpus of 247 authentic examples, drawn from eight different taped interactions between two or more speakers, totalling altogether 4 hours and 33 minutes of talk.

Four of the interactions can be characterized as informal conversations between people who know each other well: $C T$ is a telephone conversation between two female friends in their early twenties. $C V$ is a face-to-face conversation between a male and a female friend of the same age. Another face-to-face conversation, $V E$, takes place between two middle-aged female friends. Finally, the fourth, $A F$, is an informal family get-together between a young man in his early twenties, his parents, his sister, and his fiancée.

Three of the corpora are radio debates. Two of them, VS1 and VS2, are political debates with five participants: a chairperson and four journalists representing various points in the political spectrum. The third, $M P$, is a literary debate with four participants: a chairperson and three critics.

The last corpus, $M C$, is a comparatively informal examination taking place at a vocational school. There are five participants: three students, who are examined one by one, their teacher, and an external examiner.

Of the total number of closed interrogatives in these corpora, $7(2,83 \%)$ feature verb-clitic inversion, 36 (14,57\%) are marked by est-ce que, and 204 $(82,59 \%)$ have declarative word order. Like the results of previous quantitative studies carried out on actual spoken data, this suggests that SV is in some sense the basic interrogative form in contemporary spoken French, whereas $\mathrm{V}-\mathrm{Cl}$ is exceedingly rare in this medium. The distribution of the forms is, however, not identical from one corpus to the next, and none of the corpora contain examples of only a single interrogative structure. The actual figures break down as in Table 1 (Appendix).

\section{2 'Interrogatives' vs. 'questions'}

In note 1 above, I pointed out that I distinguish in this paper between 'interrogatives and 'questions', and that my analysis is concerned with the former rather 
than the latter. That is, I use the term 'interrogatives' when referring to the formal characteristics of certain utterances, and the term 'questions' when referring to functional characteristics. This is due to the oft-noted fact (e.g. Stenström 1984:2; Coveney 1996:41) that the two categories are not co-extensive. Thus, 'interrogatives' may serve a variety of different functions in discourse. For instance, the interrogatives in (21)-(25) seem to express, respectively, a request for information, a request for action, an invitation, an offer, and a suggestion ( - and still other functions could fairly easily be found):

(21) Elle a quel âge, ta sour?

'How old is your sister?'

(22) Tu me passes l'annuaire?

'Could you give me the phone book?'

(23) Ça te dirait de venir dîner à la maison demain soir?

'Would you like to come to dinner tomorrow night?'

(24) Vous voulez que je vous accompagne?

'Would you like me to accompany you?'

(25) On passe voir si Gabriel est chez lui avant d'aller à la soirée?

'Should we go see if Gabriel is at home before we go to the party?'

On the other hand, 'requests for information', for instance, can, but need not be expressed by an interrogative, as (26)-(28) show:

(26) Est-ce que Pierre est là?

'Is Pierre there?'

(27) Dis-moi si Pierre est là!

'Tell me whether Pierre is there!'

(28) Je voudrais savoir si Pierre est là.

'I would like to know whether Pierre is there.'

The present study is thus basically a semasiological one, taking a form-tofunction approach. I have chosen this over an onomasiological, or function-toform, approach because 'interrogative' is a far more easily operationalizable notion than 'question'. To my knowledge, no universally accepted definition exists which includes all the possible manifestations of functional questions and excludes all non-questions, and in any case, functional categories have a marked tendency to overlap, making it extremely difficult to draw a non-arbitrary line between one category and the next. 
I have chosen, moreover, to restrict the present study to yes/no, or 'closed' interrogatives, i.e. where the interrogative mood has scope over an entire proposition, as opposed to 'Wh-' or 'open' interrogatives, in which the interrogation concerns a specific missing element of the proposition, as in (29). The latter can be constructed in an even wider variety of ways in modern French, but there is reason to believe that the parameters determining the use of one construction rather than another in a wh-question are somewhat different from those that are relevant to yes/no questions:

(29)

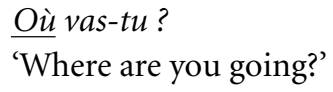

Où vas-tu?

'Where are you going?'

My data base does include so-called 'alternative' interrogatives (as in [30]), which offer the addressee a choice between two propositions, - one of which will frequently be expressed elliptically — , and which therefore cannot be answered by a simple 'yes' or 'no'. They do, however, evoke a closed set of possible answers, and each of the two propositions taken separately can, in fact, be answered by 'yes' or 'no':

(30) Tu veux du café ou du thé?

'Do you want coffee or tea?'

The semasiological angle of the present study means that interrogatives of the type in (31) have been classified as being of the yes/no variety, even though functionally they are often closer to the type of open question expressed by utterances like (29) above than they are to prototypical yes/no questions:

(31) Tu sais où elle est allée, Magali?

'Do you know where Magali went?'

Although the form of (31) makes a simple 'yes' a perfectly possible answer, it would in most circumstances be regarded as highly uncooperative behavior not to go on to specify the missing locative element if one has knowledge of it.

On the other hand, some types of utterances, which might be classified as yes/no interrogatives, have nevertheless been excluded from the data base, namely $1^{\circ}$ interrogative tags, such as $(32) ; 2^{\circ}$ a rather special type of interrogative introduced by $s i$, and which Terry (1970:53) calls 'attenuated questions', as in (33); and $3^{\circ}$ non-clausal structures such as (34), which might be analyzed as ellipted interrogatives:

(32) Luc est à Grenoble cette semaine, n'est-ce pas?

'Luc is in Grenoble this week, isn't he?' 
(33) Si on allait voir Nadine?

'How about visiting Nadine?'

(34) A. Où est Luc?

B. Il est parti à Grenoble.

A. Pour toute la semaine?

'A. Where's Luc?

B. He went to Grenoble.

A. For the whole week?

Tags have been excluded because they are not directly comparable to the three 'canonical' structures: for one thing, the clause hosting a tag is normally interpreted as an ordinary declarative unless the intonation pattern clearly indicates otherwise, and secondly, tags invariably function as orientation questions, i.e. as questions expecting a particular answer, and therefore have somewhat different pragmatic properties from the three structures studied here. Finally, the difference between the three structures considered in this paper can to a large extent be described as one of word order, whereas there is only one possible clausal tag in French, namely the frozen form n'est-ce pas. All other types of interrogative tags take the form of particles, for instance non, or hein.

$S i$-interrogatives have been excluded partly because they are not exemplified in my data base at all, and partly because they appear to have only two rather precisely circumscribed uses, one being in tentative suggestions like (33), the other in echo-questions reacting to a previous question by the interlocutor.

As for non-clausal forms, I have chosen to exclude them from the data base because it is usually impossible to determine precisely which of the three fully developed interrogative forms they might be analyzed as ellipses of.

I have, however, included a few examples (4 altogether) of apparently elliptical structures, such as (35), which are formally subordinate clauses lacking a main clause in the same utterance:

(35) PC. si vous pensez que l'actualité va être dominée par une rencontre au sommet entre:: les dirigeants $d u$ parti socialiste et les dirigeants $d u$ parti communiste, ça me fait plutôt rire parce que je croyais que cette rencontre au sommet, avait lieu tous les mercredis, au conseil des ministres, à l'Elysée CE. entre Jospin et Marchais je ne pense pas que l'un et l'autre soient membres du gouvernement

PC. parce que e: justement e, monsieu:r Fiterman et monsieur Mauroy ne so:nt pas membres l'un du parti communiste et l'autre du parti socialiste? (VS1, 15) 
'A. if you think that the news will be dominated by a summit meeting between the leaders of the Socialist party and the leaders of the Communist party, that rather makes me laugh because I thought that this summit meeting, took place every Wednesday, at the Cabinet meeting, at the Elysée palace

B. as for Jospin and Marchais I don't believe they're both members of the government

A. because er precisely er mister Fiterman and mister Mauroy are not members one of the Communist party and the other of the Socialist party?'

The reason for including these is that, on the one hand, they can be classified as SV (indeed, SV is the only possible structure for interrogatives like these), and on the other hand, it is not obvious to me that they function as true subordinate clauses and that the putatively ellipted main clause is to be sought in the previous utterance by the interlocutor. The underlined interrogative in (35) fairly clearly functions as a rhetorical question, implicating the truth of the nonnegated proposition. As such, it constitutes a counter-argument to CE's preceding assertion, and hence cannot be interpreted as offering a causal explanation of that assertion.

The data base also includes two examples which do not go to completion, because the speaker is interrupted. These two examples, which occur quite closely together in the same episode of interaction, have both been classified as ESV and will be dealt with in sect. 6.3.2 below.

A relatively small number of instances (14 altogether) of checks on the hearer's knowledge or understanding in the minimal forms tu sais ? ('you know') or tu comprends? ('you understand') have been included, while the remainder have been excluded. For certain speakers, minimal clauses of this type (which also includes tu vois ['you see'] and 2nd person plural forms) seem to be almost a linguistic tic, and they function more as a sort of discourse markers (cf. Hansen 1998a) than as interrogatives, in as much as they frequently appear in the middle of a turn, may not be spoken with rising intonation, and do not provide for an answer from the hearer, cf. the following example:

(36) ... alors bon tu vois il a une gueule qui faisait peur et tout, (h) alors déjà on lui a fi fixé une lampe ici tu vois, on lui a mis de la colle et tout ça lui faisait des gueules pas possibles, (h) et e donc là y avait cet éclairage je veux dire en pleine tête tu vois et puis on avait les spots et tout... (CV, 6)

'...well then you see he has a really ugly face and everything, (h) so to start with we st stuck a lamp on him here you see, we put glue on him 
and everything that made him look really far out, (h) and er so this light was shining I mean right in his face you see and then we had spotlights and everything...'

The inclusion of this type of example would have skewed the statistics far too much in favor of the SV structure.

Those instances which have been included in the data base are all spoken with rising intonation, they appear at the end of a turn, and for the most part they receive a verbal answer from the hearer. In the three cases where no answer is forthcoming, there is nevertheless a noticeable pause after the interrogative, and in two cases also before the interrogative, which thus appears as a genuine inquiry:

(37) A. ...quand il dit vous serez malheureuses toute votre vie c'est en fonction de ça, tu comprends?

B. ,, (h) mais e: a/ quand vous vous mariez, vou:s vous avez pas un appartement ou une maison à vous? (CT, 22)

'A. ... when he says you'll be unhappy all your lives it's to do with that," you understand?

B. ,, (h) but e:r a/ when you marry, don't don't you have your own apartment or your own house?'

Finally, there is the question of how to identify SV interrogatives with certainty in the spoken language. This is in fact not entirely unproblematical if one insists on using a strict semasiological approach, which completely separates the notions 'interrogative' and 'question'.

For one thing, the syntactic structure of SV interrogatives is identical to that of declarative sentences. Secondly, speech — unlike writing — does not feature disambiguating question marks. And thirdly, although rising intonation is considered to be a grammaticalized feature of SV interrogatives, the idea that there should be such a thing as an unambiguous 'question intonation' is - as already noted above - far from universally accepted. In other words, it is probably unavoidable that considerations of interactional function enter into the classification to some extent.

Nevertheless, although not all French SV sentences with rising intonation may be interrogatives, it does seem to be the case that SV sentences with nonrising intonation are usually not interrogatives. Thus, the vast majority ( 182 out of 202) of the utterances which I have classified SV interrogatives do feature a clearly rising intonation pattern. In 19 of the remaining 20, the intonation is not clearly falling, either, and in the one case in which there is a fall, one may 
legitimately wonder whether we are in fact dealing with an interrogative or a declarative which sums up the previous discussion:

(38) T1 A. mais dans la population égyptienne du: enfin du Delta / [B. oui] est-ce que vous / est-ce qu'on retrouve, (h) e: ce ces ces visages, $e$ : asse:z assez larges avec le:s les les grands yeux?

T2 B. comme sur les \& représentations? \&\&

T3 A. \& comme sur \&\& voilà est-ce que ça se retrouve? ça

T4 B. pas tellement, moi j'ai pas / enfin je sais pas j'ai pas trouvé non non oui \& c'est vrai \&\&

T5 A. \& parce que \&む c'est (h) \$ça se voit / c'est quand même e \$\$

T6 B. \$c'e:::st, XXX $c^{\prime}$ est $\$ \$$

T7 A. c'est une carac / ça devait être quand même assez caractéristique?

T8 B. oui mais (h) tu sais leurs yeux peut-être qu'ils faisaient des maquillages

[...lengthy discussion follows...]

T9 B. oui mais je pense e dans la population actuelle écoute bon: on s'est quand même promenés au niveau du Caire, ça nous a / ça m’a pas frappée

T10 A. ça t'a pas frappée

T11 B. non je sais pas e:,, non vraiment... (VE, 35-37)

'T1 A. but in the Egyptian population of well of the Delta / [B. yes] do you / does one find, (h) e:r the these these e:r rather rather broad faces with the: the the large eyes?

T2 B. like in the \& pictures? \&\&

T3 A. \& like in \&\& right is that to be found?

T4 B. non really, I didn't / well I don't know I didn't think so no no yes \& that's true $\& \&$

T5 A. \& because \&\& it's (h) $\$$ you see that / it's after all er $\$ \$$

T6 B. \i:::t's, XXX it's \$\$

T7 A. it's a charac / that had to be fairly characteristic after all?

T8 B. yes but (h) you know their eyes perhaps they used make-up [...]

T9 B. yes but I think er in today's population well listen we did after all go for walks around Cairo, we weren't / I wasn't struck by it

T10 A. you weren't struck by it

T11 B. no I don’t know e:r,, no really... 
My reason for including the utterance in T10 among the SV interrogatives is that the hearer B's answer in T11 seems to indicate that she interprets it as an echo-question.

\section{Results}

\subsection{SV interrogatives}

\subsubsection{B-events}

In fully 190 of the 204 instances of SV in the data base, the proposition can be classified as expressing a B-event.

1. In 80 of these examples, the participation structure is simple, the subject of the utterance is a second person pronoun, and the verb belongs to a category of predicates which have been called 'autocognitive' (Le Nestour 1978, cited in Kerbrat-Orecchioni 1991:92), meaning that they denote processes or states whose reality strictly speaking can be evaluated only by the individual who is the subject of the clause, i.e. verbs such as comprendre ('to understand'), se sentir ('to feel'), voir ('to see'), avoir faim ('to be hungry') etc.

In the second person, this type of predicate is not normally used for pure assertions, simply because it is unusual, and in most cases infelicitous, to make assertions about matters that the addressee inherently knows more about than the speaker does. As (39) shows, such assertions are possible, but they will require a rather special context (such as an examination), as well as special marking (mais si), not be understood as requests for confirmation:

(39) T1 P. donc dans quelle école étais-tu et quelle activité professionnelle astu fait dans cette école quelle(s) formation(s) professionnelle(s) astu eue(s)

T2 S. ch::: je sais pas

T3 E. mais si tu le sais c'est pas possible tu sais

T4 S. non

T5 E. tu fais un effort s'il te plaît $1--1$

T6 E. alors tu étais dans un CES? (MC, 73-74)

'P. in other words what school did you go to and what kind of vocational activity did you carry out in that school what kind of vocational training did you get

S. I::: I don't know 
E. of course you know it's not possible you know

S. no

E. make an effort please

I- - - I

you attended a CES did you?' (MC, 73-74)

Thus, the propositions underlying these interrogative clauses clearly denote B-events.

A little less than one fifth of these 80 examples express fairly straightforward information questions. In terms of the flow of the interaction, such questions frequently - but of course not necessarily - have the additional function of being topic-initiators (this is the case for instance in [40]):

(40) et qua:nd quand vous êtes e: quand vous étiez à Assouan vous avez vu la: la population noire? (VE, 32)

'and when when you are e:r when you were in Aswan did you see the: the Black population?'

(41) tu connaissais ce / tout ce système avant de commencer? (AF, 33)

'did you know this / this whole system before you started?'

(42) t'attendais mon coup de téléphone? (CT, 1)

'were you expecting my call?'

Approximately two fifths are various kinds of metadiscursive questions. These include checks on the hearer's understanding of the discourse or his memory for events and referents, as in (43)-(44). A fair number of these are instances of $t u$ vois and tu comprends found in the telephone conversation, CT (cf. [37] above):

...un peu comme y avait sur le bord de la route quand on $y$ allait en marchant tu te rappelles? $(\mathrm{CV}, 2-3)$

'... a bit like those that were at the side of the road when we went there on foot you remember?'

(44) T1 A. ...e mais si on veut le faire en été ben il y a que l'été quatre-vingtseize quoi, avant le premier mars quatre-vingt-dix-sept [laughter], vous l'avez suivi à peu près?

T2 B. \& oui \&ぬ

T3 A. \& c'est \&ఓ bon là j'ai été claire? (AF, 25)

'A. ...er but if we want to do it during the summer well there's only the summer of ninety-six, before March first ninety-seven [laughter], did you follow that more or less?

B. \& yes \&\& 
A. \& is that \&\& okay did I make myself clear?'

This category of metadiscursive questions further includes what one might call 'candidate interpretations' of the interlocutor's discourse, as in (45); and next turn repair initiators (Schegloff et al. 1977), as in (46):

(45) HA. ...deux listes, une du Rpr et une de / de l'Udf peuvent faire, cinquantetrois ou cinquante-quatre pour cent, cinquante-cinq pour cent tandis qu'une liste unique, qui va susciter à côté: des listes peti / mai / maigre importance / de faible importance qui peut faire que quarante-huit ou quarante-neuf ça serait donc, une mauvaise tactique \& électorale \&\&

CE. \& vous êtes pour \&\& deux listes alors? (VS2, 16)

'HA. ...two tickets, one for the RPR and one for / for the UDF can get, fiftythree or fifty-four percent, fifty-five percent whereas a single ticket, which on the side will give rise to sma / mea / meager size / small-sized tickets which can get only forty-eight or forty-nine so that would be, bad election \& tactics \&\&

CE. \& you're for \&\& two tickets then?'

Here, CE's question offers his interpretation of HA's previous turn, and appeals to HA for confirmation or disconfirmation.

(46) A. ...pour la soirée casino qu'on a fait tu sais, on a fait une soirée $(h) /$ / c'était comme les jeux de casino c'est-à-dire le réfectoire était complètement transformé tu vois

B. les jeux de vingt heures tu veux dire? $(\mathrm{CV}, 11)$

'A. ...for the casino night that we had you know, we had a get-together (h) / — / it was like casino games that is the dining hall was completely transformed you see

B. the eight o'clock games you mean?'

Here, B's question points to an inadequacy in A's description, thereby inviting A to repair that description in his upcoming turn.

Six examples express candidate answers, i.e. the speaker proposes an answer to a question she herself has just asked and appeals to the hearer for (dis)confirmation, as in T4 of ex. (4), sect. 1 above.

A little more than one tenth of the interrogatives in this group function as prefaces to some other action, for instance story prefaces (Levinson 1983:349):

(47) T1 A. tu as su qu'ils ont eu un accident les Walter?

T2 B. non, de quoi?

T3 A. oui oui, ils étaient à un feu rouge... 
$[\ldots]$

T4 B. e:t, ils ont pas eu de dégâts ?, eu:h de santé?

T5 A. apparemment non... (AF, 44, 47)

'A. did you hear the Walters had an accident?

B. no what kind

A. oh yes, they were waiting at a stop light...

[...]

B. a:nd, they didn't come to any harm?, e:r healthwise?

A. apparently not...'

- pre-announcements (loc.cit.):

(48) ...tu sais ce que m'a dit Katia? elle m'a dit, que t'étais TRES bien (CT, 5)

'...do you know what Katia told me? she told me, that you were VERY nice'

- $\quad$ prefaces which highlight a following statement:

(49) ...et tu sais ce qu'elle m'a dit la bonne femme? tu vas te rendre compte elle me fait dites donc mademoiselle e est-ce que vous êtes e seule? e pour aller là-bas? / - / au au sous-camp ?... (CV, 18)

'.. and do you know what this woman said to me? you'll find out she goes say miss er are you er alone? er in going down there? / - / to to the secondary camp?...'

- $\quad$ and what you might call a 'pre-explanation', which in this case moreover seems to act as a means of returning to a previous topic after a digression:

(50) T1 A. ...bon c'est des périodes comme ça j'ai envie de me marrer et je m'éclate pour un rien, bon, je suis remontée ça veut dire e ( $h$ ) que je sui:s BIEN c'est-à-dire je suis / comme si: j'avai:s / JE SAIS pas je suis remontée

T2 B. ouais bon ben voilà, t'es remontée,,, [A coughs] tu sais que tu devrais aller voir un médecin à cause de cette toux?

T3 A. ouais, je vais devoir y aller, non tu sais pourquoi jai commencé à rigoler tout à l'heure? (CT, 3 )

'A. ...well there are times like that I feel like having fun and I'll laugh at anything, well, I'm high that means er (h) that I'm feeling GOOD that is I'm / as though I had / I DON'T know I'm high

B. yeah all right OK, you're high,,, [A coughs] do you know you ought to go see a doctor about that cough?

A. yeah, I'm going to have to go see him,, no do you know why I started laughing a moment ago?' 
Notice that in some examples, e.g. (48) and (49), the speaker does not wait for an answer, the interrogative serving only to frame the following statement, which is of course the communicatively more important utterance.

Finally, there are a number of examples of indirect speech acts, including the indirect offering of advice — as in T2 of (50) above — ; indirect invitations to take the floor:

(51) ...vous pouvez nous parler un petit peu de ce stage? (MC, 75)

'...can you tell us a little bit about this work study?'

- $\quad$ and various kinds of indirect tentative assertions and evaluations:

(52) A. mais Anny, elle disait un mot tu vois ${ }^{\circ}$ toutes les nanas obéissaient ${ }^{\circ}$, alors là, faut avouer qu'elle se faisait respecter quelque chose de \& mignon \&

B. \& mais \&ぬぬ tu crois pas parce c'était parce que [A. non] c'était la sour de Patrick? (CV, 14)

'A. but Anny, she'd say one word you see ${ }^{\circ}$ all the girls would obey ${ }^{\circ}$, now there, you have to admit she commanded a lot of \& respect \&\&

B. \& but $\& \&$ don't you think 'cause she was because [A. no] she was Patrick's sister?'

(53) PC. ...il ne l'a pas encouragée il a dit simplement, que e c'était un vrai jules

RL. ne continuez pa:s à utiliser ce qui est une \& absence \&ぬ

Ch. \& vous êtes sûr(s) \&®ٌ que c'est un compliment? (VS2, 8)

'PC. ...he didn't encourage her he just said she was a real man

RL. stop using this \& lack \&\&

Ch. \& are you sure \&\& that it's a compliment?'

2. A further 34 examples have a simple participation structure and a second person subject, but the verb is not of the 'autocognitive' kind. In all cases, the context makes it clear that the hearer is in a better position to know the truthvalue of the underlying proposition than the speaker, so these examples, too, can be classified as B-events.

A little more than a third of these are fairly straightforward information questions (and in some cases also topic-initiators):

(54) A. t’as mangé?

B. (h) ouais, j'ai mangé, et toi ? (CT, 4)

'A. have you eaten?

B. yeah, I've eaten, how about you?'

(55) A. vous êtes allés jusqu'au lac?

B. oui (VE, 30) 
'A. did you go all the way to the lake?
B. yes'

(56) A. t'as trouvé le temps d'avancer encore?

B. non pas vraiment (AF, 29)

'A. did you find the time to get on with it yet?

B. no not really'

Ex. (54) is uttered in the context of a telephone conversation taking place in the evening. In (55), le lac refers to Lake Nasser in Egypt, and the context is a conversation about speaker B's recent trip to that country. Finally, in (56), the topic of A's question is her prospective daughter-in-law B's master's thesis.

A similar proportion of the examples is constituted by metadiscursive questions of various kinds: next-turn repair initiators (including two echoquestions), as in (57); candidate interpretations, as in (58); and one question that might be analyzed as a prompt, namely T6 of ex. (39) above:

(57) A. ...j'ai un / deux deux souvenirs de mariage, le mien d'abord

B. comment? tu t'es déjà marié?, mais t'es polygame alors (AF, 47)

'A. ...I have one / two two memories of weddings, first of all mine

B. what? you've been married already? but then you're polygamous'

(58) A. et vous êtes restés combien de temps alors? au Caire

B. ${ }^{\circ}$ attends je me souviens plus ${ }^{\circ}$ on a fait deux passages oui en arrivant on a dû rester deux jours, ${ }^{\circ} j$ e crois ${ }^{\circ}$ [A. oui] et puis AU RETOUR on est restés une journée, \& c'est $P E U$ \&d $\$$ en fait \$\$

A.\& oui \&\& $\$$ donc $\$ \$$ vous avez fait le le, d'abord deux jours au Caire? (VE, 16-17)

'A. and how long did you stay then? in Cairo

B. ${ }^{\circ}$ wait a minute I can't remember ${ }^{\circ}$ we went there twice yes when we arrived we must have stayed for two days, ${ }^{\circ}$ think ${ }^{\circ}$ [A. yes] and then COMING BACK we stayed for one day, \& it's not MUCH \&\& $\$$ actually $\$ \$$

A. $\&$ yes $\& \& \$$ so $\$ \$$ you spent the the, first two days in Cairo?'

Two examples are candidate answers:

(59) A. ...jétais allongée dans mon lit et je me suis endormie

B. pourquoi / t'as pris un calmant? (CT, 1)

'A. ...I was lying in my bed and I fell asleep

B. why / did you take a tranquilizer?'

And the final subgroup consists of indirect requests, some of them of a metadiscursive nature, as in (61): 
(60) A. ... alors on y va à pied ensemble alors

B. oui [to a third person] Patrick, tu portes le magnétophone? (AF, 11)

'A. ...so we'll go there together on foot then

B. yes [to a third person] Patrick, could you carry the tape recorder?'

(61) PC: ...or qui lance une contre-offensive? ben les gens qui ont été battus," alors e je ne vois pas pourquoi, Claude Estier nous reproche, à Amouroux et à moi de: dresser un constat d'échec, qui est, constat d'échec qui actuellement EST la motivation de leur politique

CE: vous permettez Charpy que je précise simplement ce que signifie cette contre-offensive?,... (VS1, 13)

'PC: ...but who launches a counter-attack? well people who've been beaten,, so I don't see why, Claude Estier blames us, Amouroux and me fo:r pointing out their failure, which is, a realization of failure which currently DOES motivate their policies

CE: will you allow me Charpy to just specify what this counter-attack is all about?,...'

3. A third, small group of nine examples have a second person accusative or dative complement in the role of experiencer and a type of verb which resembles an autocognitive predicate in as much as only the referent filling the experiencer role can really know the truth value of the proposition. These are verbs such as plaire à (='to please'), paraître à (='to seem') etc. The interrogatives in this group therefore clearly denote B-events. They function mainly as information questions (and sometimes also topic-initiators and/or indirect suggestions), but also in a couple of cases as echo-questions, i.e. as next turn repair initiators:

(62) ...on revient à la $p$ / aux chefs d'état à la politique Staline ça vous branche? (MP, 29)

'...we return to $\mathrm{p} /$ to statesmen to politics Stalin does that turn you on?'

(63) A. ...non non j'avais jamais vu mais e, 'ça , ça va, ça m'a pas choquée, [laughter] non non mais e

B. quoi / ça t'a pas épatée? (AF, 23)

'A. ...no no I'd never seen that but er, ${ }^{\circ} \mathrm{it}^{\circ}$, it's okay, it didn't shock me, [laughter] no no but er

B. what / that didn't amaze you?'

4. A fourth group consists of 67 interrogatives in which the addressee is neither the subject of the interrogative clause nor the experiencer of a predicate 
of the type just described, but which, in context, can nevertheless all be analyzed as denoting B-events.

Somewhat more than one third of the examples in this group function as information questions, occasionally of a facetious kind:

(64) P. c'était la première fois que tu faisais un stage?

S. non (MC, 79)

'P. was that the first time you had work study experience?

S. no'

(65) A. ...ton oncle il est pas encore à la maison?

B. non non non il est pas encore rentré (CT, 17)

'A. ...isn't your uncle home yet?

B. no no no he hasn't come home yet'

(66) A. ...elle nous a montré dans un temple, ${ }^{\circ}$ plus vers le sud, je sais plus si c'est à Esna, ou après ${ }^{\circ}$ e on a vu de:s des hiéroglyphes e:, qui ne sont pas, comme les autres et qu'on [B: oui] ne sait encore pas actuellement \& interpréter \&\& B. \& déchiffrer \&む

A. ouais

B. du tout?

A. ah pas du tout

B. oui

A. e avec / une répétition d'animaux de têtes d'animaux hein je ne sais plus \& lesquels er

B. \& mai:s \&\&

A. j'ai oublié

B. on arrive à les dater un petit peu quand même? (VE, 53)

'A. ...she showed us in a temple, ${ }^{\circ}$ further to the south, I can't remember whether it was Esna, or after ${ }^{\circ}$, er we saw so:me some hieroglyphs e:r, which are not, like the others and which they [B. yes] don't yet know how to \& interpret \&\&

B. \& decipher \&\&

A. yeah

B. not at all?

A. oh no not at all

B. yes

A. er with / a sequence of animals of animals' heads you know I can't remember \& which ones \&\&

B. \& but \&\&

A. I've forgotten 
B. can they put an approximate date on them at least?'

(67) A. bon, alo:rs, oui bon la tradition veut $Q U E$, ça ne bouille pas

B. mais / comment tu le trouves

[whistling]

C. $X X X$

B. en général, la tradition veut qu'on y arrive pas et qu'on s'énerve et qu'on le / [laughter] met le cognac sur le truc alors que c'est pas \& XXX ? \& A. \& non non e むd (AF, 9)

'A. ...well, no:w, yes well tradition has it THAT, this shouldn't boil

B. but / how do you find it [whistling]

C. XXX

B. in general, does tradition have it that you shouldn't be able to manage and that you should get annoyed and that you should / [laughter] pour the cognac on the thing even though it isn't \& XXX ? \& \&

A. \& no no er \& \&

In (64), the question directly concerns the hearer's past biography. In (65), the interlocutors are speaking to each other over the telephone. B lives with her uncle and is at home during the conversation, so she can safely be assumed to be in a much better position than A to know whether her uncle has come home yet. And in (66)-(67), the contents of previous turns show that the hearer is more likely than the speaker to know the truth value of the proposition (cf. also T4 of [47], sect.6.1.1 above).

30 examples from this group are of a metadiscursive nature, more specifically echo-questions and other next turn repair initiators:

(68) A. ...c'est-à-dire ils ils étaient comme le le / ils étaient attachés à la terre aussi comme le serf c'est vrai,

B. ils étaient attachés à la terre?

A. ah oui oui oui (VE, 45)

'A. ...that is they they were like the the / they were tied to the land too like a serf it's true,,

B. they were tied to the land ?

A. oh yes yes yes'

(69) A. ...et en plus Katia elle t'a pas du tout mis mal à l'aise - -

B. mais elle MET les gens mal à l'aise quand elle les aime pas? (CT, 8)

'A. .... and what's more Katia didn't make you feel ill at ease at all - -

B. but DOES she make people feel ill at ease when she doesn't like them?' 
- $\quad$ attempts to ascertain shared reference or mutual comprehension (cf. also T3 of ex. [44] above):

(70) A. alors donc y en avait y avait donc trois soeurs / - / le l'espèce de curé maudit qui était cette espèce de petit mec qui s'appelait Antoine? / — / il s'appelait Antoine je sais pas si tu te rappelles qui avait vraiment une gueule il était mal foutu e

B. ah non pas du tout hein [...]

B. attends, sa mère travaillait dans les produits de parfum c'est pas ça?

A. je crois pas non c'était c'était c'était Antoine Darnel il s'appelait

B. il est venu avec moi à la seconde semaine avec Marco? (CV, 4-6)

'A. well there were there were three nuns in other words / - / the this cursed priest who was this little guy named Antoine? / - / his name was Antoine I don't know if you remember who had a really ugly face er B. oh no not at all [...]

B. wait, his mother was in the cosmetics business isn't that right?

A. I don't think so no it was it was it was Antoine Darnel was his name

B. did he come with me the second week with Marco?'

- candidate interpretations:

(71) A. ...donc $i$ : ils auraient un autre / une autre voiture

B. c'est-à-dire ils ont ils en ont racheté une? (AF, 47)

'A. ...so th: they would get another / another car

B. you mean they they bought a new one?'

- $\quad$ and one question about turn taking from a participant to the chairperson of a radio debate:

(72) Ch. bon alors on peut parler on peut parler du contenu? e sur e: Jean-Didier ?

JDW: c'est moi qui doit commencer? (MP, 4)

'Ch. so anyway can we talk can we talk about the contents? er about e:r Jean-Didier?

JDW: do I have to start?'

And a final sub-group consists in indirect speech acts of various kinds, mainly from the radio debates, and mainly of a metadiscursive kind: 
(73) Ch. bon, alors,, Henri Amouroux je crois qu'il vaut mieux arrêter \& sur ça parce que ed

HA: \& on parle du Liban? \&ぬ

Ch. là on va pas refaire $\$$ l'histoire $\$ \mathbb{S}$

HA: $\$$ on parle $\$ \$ d u$ Liban?

Ch. alors moi je / on va effectivement parler du Liban, ... (VS1, 19)

'Ch. so, now,, Henri Amouroux I think it's best to stop \& discussing this because \&\&

HA: \& can we talk about Lebanon? \&\&

Ch. we're not going to rewrite $\$$ history $\$ \$$

HA: $\$$ can we talk $\$ \$$ about Lebanon?

Ch. so I / we are indeed going to talk about Lebanon,...'

(74) T1 A. et on peut pas le faire / faire flamber d'alcool et le mettre par-dessus? \& le verser par-dessus en flambant? \&®u mais sans / sans le faire flamber à même le gâteau

T2 B. \& si, c'est ce que je vais faire \& \&

T3 B. c'est ce que je vais essayer de faire, est-ce qu'on a u:/ un briquet ou quelque chose... (AF, 6)

'A. and can't we flambé it with alcohol and put it on top? \& pour it on top while flambéing? \&\& but without flambéing it on the cake itself B. \& yes, that's what I'm going to do \&\&

B. that's what I'm going to try to do, do we have a:/ a lighter or something...'

\subsubsection{Non-B-events}

$14 \mathrm{SV}$ examples expressing non-B-events remain to be analyzed. Seven of these are quotes. This means, of course, that no evaluation of the underlying proposition is solicited from the current addressee. According to the hypothesis of the present paper, we would therefore expect SV to be infelicitous in these examples.

However, all these quotes are clearly marked as such ahead of their production through the use of the verbs dire ('to say') and faire ('to go'), so the chance is quite small that the current addressee will interpret these interrogatives as directed to him. Furthermore, six of the examples have a second person subject, and in all seven, the proposition expresses a B-event in the quoted, if not in the quoting context: 
(75) Ch. ... y a sûrement un livre que vous avez lu tous les trois c'est le livre que Pierre Assouline a consacré à Galli / Gallimard Gaston Gallimard \& Gallimard \&e

JG: \& Gaston Gallimard \&d

Ch. oui Gaston oui là aussi faut préciser le prénom parce qu’ils sont plusieurs JG: oui et puis en plus on l'appelle Gaston maintenant j'ai remarqué que depuis que le livre a paru tout le monde dit vous avez vu e biographie de Gaston? comme si c'était un:

FX: un pote (MP, 17)

'Ch. ...I'm sure there's one book which all three of you will have read it's the book that Pierre Assouline has written about Galli / Gallimard Gaston Gallimard \& Gallimard \&\&

JG: \& Gaston Gallimard \&\&

Ch. yes Gaston yes there too you have to specify the first name because there are several of them

JG: yes and moreover people call him Gaston these days I've noticed that since the book appeared everybody's saying did you see er biography of Gaston? as though he were a:

FX: a pal'

(76) ...parce que tous les deux jours on allait chercher l'argent alors ça je te dis pas ils en avaient RAS-le-bol qu'on leur dise ben tu peux pas m'apporter mille francs aujourd'hui? (h) tu peux pas venir m'apporter un kilo de sucre ? parce qu'on a plus de sucre... (CV, 22)

'...because every other day we'd go get money now believe me they were SICK of us saying to them can't you bring me a thousand francs today? (h) can't you bring me a kilo of sugar? because we have no sugar left...'

Furthermore, in four examples (including the two in [76]), the verb is negated, making ESV an unlikely alternative. V-Cl, on the other hand, would appear stilted in at least five of the examples, in so far as the quoted context is one of young equals addressing each other.

There is one example (T6 of ex. [4], sect. 1) where one might wonder why $\mathrm{V}-\mathrm{Cl}$ wasn't used, as this structure is used in an immediately following quoted interrogative. Nevertheless, we might hypothesize that the contrast between the two interrogatives is in fact meaningful: in a context where one has dialed a friend's phone number, one has reason to expect that the person answering the phone will be a member of that friend's family - if not the friend herself. This makes the first SV interrogative in the extract relatively assertable. When asking if she can speak to her friend, however, the speaker is on shakier ground 
because she has no way of knowing whether her friend is at home at the time of the call. Moreover, she is speaking to a socially distant, older interlocutor with whom she will want to be on good terms. Therefore, she uses $\mathrm{V}-\mathrm{Cl}$ in this interrogative to convey deference and uncertainty of the answer.

One of the last seven examples is the causal clause already discussed in (35), sect. 5.2 above. Here, both $\mathrm{V}-\mathrm{Cl}$ and ESV would be ungrammatical. That leaves us with six SV examples to explain.

Two of these are straightforward requests for confirmation (one of them of a metalinguistic nature) as in (77); one - T7 of ex. (38), sect. 5.2. above is halfway between a request for confirmation and a tentative assertion; and one is halfway between a request for confirmation and a self-addressed question (78):

(77) A. le seul mariage où je suis allé c'étai:te, tu sais c'était avec

B. la réception

A. je crois, c'était avec e, c'était Lamotte je crois c'est ça hein, c'est Lamotte?

B. $m m$

A. qui se mariait? (AF, 48)

'A. the only wedding I've been to wa:s er, you know it was with

B. the reception

A. I think, it was with er, it was Lamotte I think that's it right, is it Lamotte?

B. $\mathrm{mm}$

A. who got married?'

(78) A. et vous y êtes allés comment?

B. en avion

A. en avion [B. oui oui] oui parce que ça fait e:

B. je sais pas Daniel il dit deux cents trois cents kilomètres? non ? ${ }^{\circ}$ 'est pas ça?

A. à mon \& avis \&ぬ

B. \& six cents \&\& six cents (VE, 21)

'A. and how did you get there?

B. by plane

A. by plane [B. yes yes] yes because it comes out to e:r

B. I don't know Daniel says two hundred three hundred kilometers? no? isn't that it?

A. in my \& opinion \&\&

B. \& six hundred \&\& six hundred' 
Requests for confirmation have a clear assertive component which justifies the use of SV; indeed, declarative syntax is used to express requests for confirmation in other languages, such as English or German, which otherwise use verbsubject inversion in interrogatives much more systematically than French does.

One example is halfway between a rhetorical question implicating the negation of the proposition and a next turn repair initiator:

(79) CE. ...et, je crois véritablement que ce n'est pas très sérieux, de traiter, les problèmes de: l'appartenance du parti communiste au gouvernement de cette façon-là,, nous avons un certain nombre de problèmes

PC. y a une façon sérieuse de la traiter?

CE. oui il y a une façon sérieuse c'est justement celle qu'a employée Lionel Jospin cet après-midi... (VS1, 5-6)

'CE. ... and, I really do think that it's not very serious, to treat, the problems linked to: the Communist Party's membership of the government in that way,, we have a certain number of problems

PC. is there a serious way of treating it?

CE. yes there's a serious way it is precisely the one that Lionel Jospin chose this afternoon...'

To the extent that the question is a rhetorical one, we would expect it to have been expressed by $\mathrm{V}-\mathrm{Cl}$ or ESV, and indeed both these structures would have been perfectly natural in this context. However, as a next turn repair initiator which questions a presupposition of the addressee's previous turn, the utterance explicitly appeals to that addressee for a reaction, and succeeds in getting one, as the following turn shows.

The last two examples are indirect suggestions (the one in [81] presumably facetious) made in the context of negotiating a joint family project, namely a wedding:

(80) A. non mais en fait ça pourrait pas / ça pourrait pas être le vingt-hui:t février?,, \& c'est quand même \&ڤ

B. ah \& si vous voulez, \&\& mais c'est moins / c'est moins gai quoi [laughter], enfin moi j'aurai préféré $\$$ l'été pour e $\$ \$$

A. $\$$ point de vue saison $\$ \mathbb{S}(\mathrm{AF}, 26)$

'A. no but actually couldn't it / couldn't it be February twenty-ei:gth?,, \& after all it's \&\&

B. ah \& if you like, \&\& but it's less / it's less fun you know [laughter], in any case I'd prefer $\$$ the summer for e $\$ \$$

A. $\S$ from the point of view of the season $\$ \S^{\prime}$ 
(81) B. non non e: mairie ${ }^{\circ}$ quo $i^{\circ}$ mairie, mais e:,

C. quoique mairie Santini:, e: c'est pas forcément mieux qu'une église bretonne

B. ouais bien sûr bien sûr mais

A. ben normalement c'est le lieu de: / de son: $(h)$

C. sa résidence?

A. e rés / \& sa résidence \&\&, de son domicile ${ }^{\circ} q u o i^{\circ}$

B. \& de: / m ouais ouais \&\&

C. ouais ouais c'est ça,,,

B. ouais c'est bien dommage, mais ${ }^{\circ}$ bon $^{\circ}$ on fera avec ${ }^{\circ}$ hein ${ }^{\circ}$

C. on peut déménager avant juin? (AF, 6a)

'A. no no e:r town hall town hall, but e:r,'

B. although the Santini: town hall, e:r is not necessarily better than a Breton church

A. yeah sure sure but

C. well usually it's the place o:f / of you:r (h)

B. your residence?

C. e res / \& your residence $\& \&$, of your home ${ }^{\circ}$ you know ${ }^{\circ}$

A. \& o:f / m yeah yeah \&\&

B. yeah yeah that's it,",

A. yeah it's a shame, but ${ }^{\circ}$ well ${ }^{\circ}$ we'll live with it ${ }^{\circ}$ won't we ${ }^{\circ}$

B. can we move before June?'

In (80), the mother of the groom suggests a wedding date to her prospective daughter-in-law, while in (81) the groom suggests to his fiancée that they move before the wedding in order to avoid having to get married in an unattractive town hall. In neither case can the addressee settle the matter alone, and as we are dealing with matters that are still being negotiated, both interrogatives must be classified as expressing D-events. However, in both cases, it is not just an opinion on the matter, but the opinion of this specific addressee (the bride-tobe) which is solicited. Moreover, the speakers both play an important role in the decision-making process, which entitles them to a certain amount of assertiveness in their suggestions.

\section{2 $\mathrm{V}-\mathrm{Cl}$ interrogatives}

As Table 1 shows, there is a total of only seven $\mathrm{V}$-Cl structures in the data base, six of which occur in the two political debates, VS1 and VS2. Five of the examples have only a pronominal subject, while two have an additional, coreferential NP subject. 
Six of these interrogatives denote non-B-events in their context of utterance. In the debates, there are four topic-initiating questions, all of which can be classified as D-events:

(82) Ch.: ... si quelqu'un avait e un doute il doit être dissipé l'Europe est et reste malade, l'échec du sommet d'Athènes était un peu: prévisible c'est vrai, alors, l'Europe est-elle en voie de di:slocation, ou bien finalement ne peut-on pas essayer de tirer parti un peu de cet échec la France ( $h$ ), doit assurer la présidence de la communauté à partir de janvier et pour six mois c'est-àdire en période importante (h) puisqu'il y aura les / les élections à l'Assemblée européenne, alors peut-on espérer oui ou non e, un déblocage ou est-ce encore du rêve Henri Amouroux (VS2, 1)

'...if anyone had er any doubts they must have been dispelled Europe is and remains sick, the failure of the Athens summit was a bit predictable it's true, so, is Europe falling apart, or can't we after all try to get some small benefit out of this failure France (h), will be presiding the EC for six months from January that is at an important moment (h) since elections for the European Parliament are coming up, so can we yes or no expect er, a solution or it that still just dreaming Henri Amouroux'

Here, the journalist chairing a political debate is putting forth a first topic for discussion amongst the participants. The two questions differ on certain points, however. While both ESV and SV would be possible realizations of the second question (peut-on oui ou non...), only $\mathrm{V}-\mathrm{Cl}$ seems truly felicitous in the first instance (l'Europe est-elle...). Part of the explanation should no doubt be sought in the fact that the first question is asked of no one in particular, but only serves to signal that here is a topic that is worth pondering. Indeed, as the continuation shows, the speaker does not stop to make room for any answer at all. The second question, on the other hand, is directed to a specific participant, who is thereby designated as the evening's first discussant.

Secondly, the presence of a negation in the second disjunct of the first question (ne peut-on pas essayer...) is noteworthy. Interrogatives of this type, whether they be realized as $\mathrm{V}-\mathrm{Cl}, \mathrm{ESV}^{14}$ or SV, are generally oriented towards a positive answer, but when realized as $\mathrm{V}-\mathrm{Cl}$, they typically go further and function as rhetorical questions, that is, as actually implicating a positive assertion, as shown in (83):

N'a-t-on pas tout fait pour lui?

'Haven't we done everything for him?' 
As such, they neither require nor expect an answer. This interpretation is possible with negated SV interrogatives as well, but it is much less common. Now, in (82), the negated clause does seem to implicate at least a tentative positive assertion on the order of Surely, we can try to get some small benefit out of this failure. This means that the pragmatic meaning of the clause contrasts with the meaning of the first alternative l'Europe est-elle en voie de dislocation. It's semantic meaning, however, is co-oriented with that of the first clause. If $\mathrm{V}-\mathrm{Cl}$ were replaced with SV in this example, the disjunction would therefore appear infelicitous, in so far as disjunctions carry a generalized quantity implicature to the effect that the two propositions are mutually exclusive (cf. Levinson 1983:139).

A fifth interrogative displays a complex participation structure, as it represents a quote of a hypothetical self-addressed question asked by a nonpresent, a relatively vaguely defined, group of people, and which does not elicit an answer from anyone present:

(84) Chairperson: alors tout à l'heure, Roland Leroy a fait allusion à la pensée de Monsieur Lecanuet la phrase exacte était effectivement de Jean Lecanuet, ma tête est pour deux listes mes pieds j'en suis moins sûr cette formule un peu imagée, pour expliquer les hésitations \& de l'Udf \&ぬ

RL: \& je répète \&\& que je ne sais pas avec quoi il pense Ch. voilà e je ne sais pas, il a pas encore tout à fait répondu à la question peut-être $\$$ qu'il pense deux fois, l'une avec sa tête l'autre $\$ \$$ avec ses pieds CE: $\$$ il n'est pas sûr de penser avec ses pieds $\$ \$$ Ch. en tout cas, les hésitations de l'Udf faut-il: deux listes dans l'opposition une seule pour les élections européennes, visiblement l'Udf semble s'en remettre... (VS2, 12)

'Chairperson: well then a moment ago, Roland Leroy alluded to $\mathrm{Mr}$ Lecanuet's thoughts indeed he quoted Jean Lecanuet verbatim, my head is for two tickets my feet I'm less certain this somewhat metaphorical formulation being meant to express the hesitation \& of the UDF \&\& RL: \& I repeat \&\& that I don't know what he thinks with Ch. right er I don't know, he hasn't really answered the question yet perhaps $\$$ he thinks twice, once with his head the second time $\$ \$$ with his feet CE: $\S$ he is not sure that he thinks with his feet $\$ \S$

Ch. in any case, the hesitation of the UDF does the opposition need two tickets a single one for the European elections, clearly the UDF seems to be getting over it...' 
The last two V-Cl interrogatives, (85) below and T6 of (4), sect. 1 above - the latter being the one example which occurs in mundane conversation - , are both requests for permission which feature the almost frozen collocation of the modal verb pouvoir in the 1. person singular, viz. puis-je ('can I') and pourrai(s)-je ('could I'):

(85) RL: ...je trouve que le:s coopérants cubains, les travailleurs cubains qui étaient là-bas et qui portaient assistance et aide au peuple grenadin o:nt montré une fois de plus combien Cuba est dans une position forte dans la lutte contre / l'imp / contre l'impérialisme américain e, dans la mer des Caraïbes, et combien et combien ils ont eu, ici un grand, mérite

HA: avec votre permission

RL: je veux, je veux ajouter deux faits

HA: puis-je vous interrompre? (VS1, 24)

'RL: ...I think that the Cuban collaborators, the Cuban workers who were there and who gave assistance and aid to the people of Grenada have shown once more how strong a position Cuba holds in the struggle against / imp / against American imperialism er, in the Caribbean Sea, and how and how much, praise is due to them in this case

HA: with your permission

RL: I want, I want to add two facts

HA: may I interrupt you?'

T6 in ex. (4) occurs in reported speech, thus displaying a complex participation structure, and purports to quote a hypothetical request for permission made to a socially distant interlocutor, which may moreover be classified as a non-B-event in the quoting context. By using $\mathrm{V}-\mathrm{Cl}$, the speaker simultaneously indicates that an answer is not expected from her current interlocutor, and expresses a degree of deference appropriate to the hypothetical interlocutor by explicitly wondering about whether permission to speak with 'Murielle' will be granted.

In (85), on the other hand, the participation structure is simple: the speaker takes full responsibility for the utterance, which is explicitly addressed to a copresent hearer, and we are dealing with a metadiscursive utterance, whose only function is to locally regulate the interaction between speaker and hearer, its content in itself being of no interest to the audience. Moreover, I think the proposition expressed must be analyzed as a B-event, since it is - at least in principle - up to the hearer to decide whether or not to grant his permission. We would therefore expect SV. However, the hearer RL has been speaking at some length prior to this point, only interrupted by a few opposing remarks 
from a third speaker PC, who is not featured in the extract, whereas HA has in principle already had his say on the subject earlier. Moreover, when HA first attempts to take the floor, RL clearly indicates that he is not ready to relinquish it (je veux, je veux ajouter deux faits). It therefore seems quite appropriate for HA to explicitly wonder about the feasibility of interrupting.

\subsection{ESV interrogatives}

\subsubsection{Non-B-events}

Of the $36 \mathrm{ESV}$ interrogatives in the data base, 22 are non-B-events.

1. One group of seven examples consists in quoted interrogatives. Here, the current addressee is clearly not being appealed to for a reaction to the proposition, the more so as six of the examples occur in the context of a narration of past events (e.g. the second interrogative of [49], sect. 6.1.1 above, and [86] below), while the seventh is a hypothetical quote intended to illustrate a general attitude attributed to a non-present third person (87). In the quoted contexts, three of the interrogatives function as requests for information (49), while another three function as indirect requests for action or permission (86)-(87). The one remaining example seems to be on the borderline between these two categories:

(86) ... hier quand je lui ai demandé de t'appeler, s si e je lui dis écoute est-ce que tu peux appeler Murielle pour lui dire, que e: je suis à la fac, elle t'a appelée et elle t'a demandé quand est-ce que tu viendrais,... (CT, 15)

'...yesterday when I asked her to call you, $<$ s si $>$ er I say to her can you call Murielle and tell her, that er I'm at the university, she called you and she asked you when were you going to come,...'

(87) JDW. non Assouline est spécialisé dans les biographies dont il ne rencontre jamais le:s les gens

FX. oui

JDW. n'est-ce pas il a fait un Dassault qui n'a jamais voulu le voir \& Dassault absolument extraordinaire/むd

JG. \& et ce que / et ce que / et ce qui a / ce qui a fait dire à un critique qu'il était passé és du café du commerce au bar du Port Royal ce qui est une jolie expression

JDW. [laughter] oui c'est ça [laughter] $\$$ e:t $\$ \$$

FX. $\$$ sur quoi il $\$$ S travaille là 
JDW. mais je sais pas il / il il demande est-ce que vous acceptez que je fasse votre biographie? [laughter] dès qu'on dit non il la fait [laughter] (MP, 24)

'JDW. no Assouline specializes in biographies o:f of people he never meets FX. yes

JDW. right he wrote one about Dassault who never agreed to see him \& absolutely extraordinary Dassault / \&\&

JG. \& and which / and which / and which made / and which made one critic say that he'd passed from the Commerce café to the Port Royal bar which is a lovely expression

JDW. [laughter] yes that's it [laughter] $§$ a:nd $\$ \S$

FX. $\$$ what is he $\$ \$$ working on now

JDW. but I don't know he / he he'll ask will you allow me to write your biography? [laughter] and when the person says no he writes it [laughter]'

2. A second group of nine examples comprises self-addressed questions. In none of these cases is it expected or even hoped that the addressee will provide an evaluation of the proposition: in eight cases, the speaker himself immediately goes on to provide the answer, while in the remaining one (ex. [6], sect. 1 above), the context makes it clear that the addressee is unable to do so:

...qu'est-ce qu'on peut dire / ce qui est / la révélation de ce livre est-ce qu'il $y$ a des révélations d'abord non / la révé / c'est la continuité qui est ahurissante, n'est-ce pas... (MP, 11)

'...what can you say / what is / the revelation of this book first of all are there any revelations no / the reve / it's the continuity which is unbelievable, isn't it...'

(89) ...il faut dire également qu'il y a une chose curieuse, c'est que contre qui les Américains se battent-ils, est-ce qu'ils se battent contre les forces, des petites forces de police de ce pays, pas du tout, j'ai pas l'impression, en tout cas on le sait pas... (VS1, 21)

'...you have to say also that there's something funny, that is who are the Americans fighting, are they fighting the forces, some small local police forces, not at all, it's not my impression, in any case we don't know...'

(90) A. mai:s y a des textes anciens qui: qui indiquent qu'y avait déjà plusieurs récoltes par an \& $X X$ \&

B. \& ah bon \&\& parce que là ils nous disent maintenant ON peut faire trois récoltes avant on pouvait pas, [A. e:] alors je sais pas moi tu sais ${ }^{*}{ }^{*} e s t c e$ qu'elle nous dit maintenant ${ }^{*}$ hein moi je: / — / 
A. e peut-être que a / aVANT le barrage

B. avant le barrage [A. voilà] ouais (h) depuis qu'y a le barrage ils font plus de récoltes ${ }^{*}$ enfin ${ }^{*}$ c'est ce qu'elle dit maintena:nt, (h) est-ce qu'avant on en faisait / oh y avait peut-être des endroits où ils pouvaient faire e BEAUCOUP de récoltes aussi... (VE, 26-27)

'A. bu:t there are old texts whi:ch which indicate that they were already harvesting three times a year \& XX \&\&

B. \& really $\& \&$ because now they tell us these day WE can harvest three times before they couldn't, [A. e:r] so I don't know you know ${ }^{*}$ that what she tells us now ${ }^{\star}$ you know I: / - /

A. er perhaps be / beFORE the dam

B. before the dam [A. right] yeah (h) since they built the dam they can harvest more often ${ }^{\star}$ anyway ${ }^{\star}$ that's what she says no:w, (h) did they do it before / well there might have been places where they could harvest er VERY frequently too...'

In all cases, what is conveyed by these interrogatives is that the proposition expressed is one which the context makes it relevant to wonder about. If ESV were replaced by SV in these examples, the function of the utterances would change into straightforward requests for information. Thus, to take one example, the SV construction je suis libre? would be totally inappropriate in (6), but would be natural if addressed, for instance, by a hostage who had just been set free to her liberators.

3. One example is a positive rhetorical question oriented towards a positive answer:

(91) RL....je dois dire puisque,,, vos auditeurs le savent, puisque le journal en a fait état tout à l'heure que Charles Fiterman a démenti avec la plus grande vigueur, cette affabulation, du journaliste du Monde, en réalité une affabulation qui s'inscrit dans une sorte de, de campagne de: menée depuis un:: certain nombre de jours puisque c'est ici même, à votre micro il y a quarante-huit heures que Charles Fiterman rappelait, j'ai, j'ai sous la / la main, ici, le script de son émission, qu'il était au gouvernement et qu'il entendait y rester, naturellement, e::

PC. pardon une petite précision, est-ce qu'il avait bien voulu démissioner en mars e quatre-vingt-trois?

RL. e: naturellement qu'il est / qu'il est / qu'il est tout à fait évident et Charles Fiterman l'a dit, ici, à ce micro, il le répète ce soir qu'il / est co / l'affirmation de:, d'une intention de départ est absolument inventée,... (VS1, 1) 
'RL....I have to say since,, your audience knows it, since it was dealt with in the news a moment ago that Charles Fiterman has most emphatically denied, this fantasy, of Le Monde's reporter, actually a fantasy which is part and parcel of a sort of, of campaign o:f, waged for a certain number of days now given that it was here, at this station forty-eight hours ago that Charles Fiterman reminded us, I have, I have in my / my hand, here, the script of that broadcast, that he was a member of the government and that he intended to remain so, of course, e::r PC. excuse me, let's just make this clear, didn't he want to quit in March eighty-three?

RL. e:r of course it is / it is / it is quite obvious and Charles Fiterman said so, here, on this station, he's repeated it this evening that it is / is co / the allegation that he intends to quit is entirely invented,...'

Although the truth of the proposition can be assumed to be known to all the participants in the debate, making this an O-event, the presence of the assertive particle bien (cf. Hansen 1998b) indicates that some unspecified individual might nevertheless be inclined to deny it, and indeed the contents of the hearer's previous turn might lead one to infer that it could not be true. By his use of ESV, then, the speaker is signaling that the previous turn seems to make it relevant to wonder about the very reality of a proposition that might otherwise have been taken for granted. Rhetorically, the function of this question is to sow doubts in the audience's mind about the assertions made by the interlocutor RL, who is the speaker's political opponent.

Had SV been used, the utterance would have functioned more like a simple request for confirmation, and the implication would have been that, rather than the proposition being a matter of common knowledge, RL could be expected to be more knowledgeable about Charles Fiterman's past intentions than the other participants, including the speaker.

4. Three examples are requests for the addressee's opinion about a D-event. Additionally, one of these functions as a topic-resuming question (92), i.e. together with the question immediately preceding it, ${ }^{15}$ it marks the return to a previous phase of the interaction after a rather lengthy digression, while another example (93) is a repeat/paraphrase of an earlier question:

(92) Ch. ...bon écoutez on va pas faire le: hein / [laughter] le: le hit parade des regrets que vous pouvez avoir dans l'épuration [laughter]

JDW. non c'est pas des regrets mais / 
JG. [laughter] je remarque qu / qu'avec Jean-Didier on retombe tout le temps sur la politique hein

Ch. ah mais c'est /

JG. $i$ / il a

[laughter]

JDW. c'est très \& intéressant la politique \& \&

FX. \& il connaît bien il connaît êd bien hein

JDW. j'aime bien

Ch. oui c'est pour ça qu'on peut regretter que Poirot soit pas là aussi parce que Poirot est déchaîné là-dessus / mais je voudrais e / une question e: que je voudrais vous poser à tous les trois vous ête:s / tout à fait excités par cette: biographie mais est-ce que vous pensez (h) que vous n'êtes pas un peu déformés vu votre spécialité est-ce que le grand public

FX. absolument

Ch. celui qui va chez le libraire du coin \& acheter \&\& son folio JDW. \& ah oui \&\&

FX. ah oui

Ch. $\underline{v / v a / v a ~ e ̂ t r e ~ p a s s i o n n e ́ ~ o u ~ e s t ~ d e ́ j a ̀ ~ p a s s i o n n e ́ ~ p a r ~ l e: ~ l ' A s s o u l i n e ~(M P . ~}$ 25-26)

'Ch. well listen we're not going to make a: you know / [laughter] a: a top ten list of the regrets that you have with respect to the aftermath of the Liberation [laughter]

JDW. no they're not regrets but /

JG. I've noticed th / that with Jean-Didier we always end up talking politics you know

Ch. oh but it's /

JG. h / he has

[laughter]

JDW. politics is \& very interesting \&\&

FX. \& he knows a lot about it he knows \& \& a lot about it you know JDW. I like it

Ch. yes that's why we should have had Poirot here too because Poirot is passionate on the subject / but I wanted to er / a question e:r that I wanted to ask all three of you you're: / completely excited about this biography but don't you think (h) that you're a bit biased by your specialization will the public at large

FX. absolutely

Ch. those that go to the corner bookstore \& to buy \&\& their paperbacks JDW. \& oh yes \&\& 
FX. oh yes

Ch. b / be / be fascinated or are they already fascinated by Assouline's book'

(93) [debate launched by the chairperson on whether or not the two right wing opposition parties should put forward two separate tickets for the upcoming elections to the European Parliament]

Ch. Roland Leroy

RL. ben e: la question pour la droite de fai:re une liste ou deux listes e c'est son affaire après tout, c'est tout à fait son affaire

[several turns later]

RL. alors à / à propos / à propos des listes e, e les élections européennes ont lieu, à la représentation proportionnelle c':est en effet l'occasion pour chaque parti d'être représenté pour ce qui nous concerne, e c'est / c'est de cette manière, que nous le / que nous concevons l'élection e, d'une façon toute simple Ch. est-ce que pour e pour la majorité pour la gauche, c'est mieux d'avoir une liste ou deux listes de l'opposition

RL. ben je viens de vous (VS2, 16-17)

'Ch. Roland Leroy

RL. well e:r the question of whether the right shou:ld put forward one or two tickets er that's their business after all, it's entirely their business [...]

RL. so with / with respect / with respect to the tickets er, er the European elections will be proportional elections i:t's indeed an occasion for each party to be represented as far as we're concerned, er it's / it's in this way, that we, that we see the elections er, quite simply

Ch. for er for the majority for the left, is it better to have one or two opposition tickets

RL. well just now I'

5. Finally, two examples express AB-events, in as much as their subject is referentially, if not formally in the 1st person plural (i.e. we are dealing with the 3rd person singular generic pronoun on, which in the spoken language is regularly used instead of the more formal nous), while the verb is in the present tense. This is what we find in T3 of ex. (74), sect. 6.1.1 above. Here, ESV disambiguates the utterance, which might otherwise have been interpreted as a statement, the more so since the utterance immediately preceding it is a statement about an A-event. The second example follows shortly upon this one in the same interaction and is a paraphrase of T3, and so the use of the emphatic ESV structure is even more justified there. 


\subsubsection{B-events}

1. Of the remaining 14 examples denoting B-events, four examples are repetitions or paraphrases of earlier questions which the speaker feels have not been properly answered. The ESV construction is the most appropriate one for this purpose, being more emphatic than either $\mathrm{V}-\mathrm{Cl}$ or SV. This, as I have hypothesized above, is presumably due to its focusing on the reality of the proposition (cf. also T7 of [4], sect. 1 above):

(94) Ch. ...en revanche, dans l'opposition, certains, ont l'air e: de / de ne pas être tout à fait hostiles ou en tout cas, assez compréhensifs e à l'égard de cette intervention américaine, Pierre Charpy

[several turns later]

Ch. e, Henri Amouroux

HA. oui, il faut dire tout d'abord...

[several turns later]

Ch. mais sur le fond tout de même Henri Amouroux est-ce que \& vous le comprenez ou non? \&\&

HA. \& sur le fond, je ne suis pas \&\& non sur le fond je ne suis pas enthousiaste / je veux dire enthousiasmé par cette opération... (VS1, 20-22)

'Ch. ... on the other hand, some people, from the opposition, seem e:r to / to not be completely hostile or in any case, fairly understanding er towards this American intervention, Pierre Charpy

[...]

Ch. er, Henri Amouroux

HA. yes, first of all I have to say...

[...]

Ch. but anyhow when it comes down to brass tacks Henri Amouroux do $\&$ you understand it or not? \&\&

HA. \& when it comes down to brass tacks, I'm not \&\& no basically I'm not an enthousiast / I mean enthousiastic about this operation...'

2. Seven examples are topic-initiating or topic-resuming questions. These either mark the beginning of a new phase in the interaction or the return to a previous topic after a digression of some length:

(95) [discussion of a biography about the publisher Gaston Gallimard has just come to an end]

JG. est-ce que je peux dire un \& un petit mot Pierre \&\& Bouteiller de la / de le:s / de c'aut / zat / cette / cette autre biographie d'éditeur \$ e::t \$\$

PB. \& oui Jérôme erd 
Soui Michel Calman-Lévy \$\$ oui (MP, 28)

'JG. can I say one \& just one word Pierre \&\& Bouteiller about the / about the: / about th'other / zoth / this / this other publisher's biography $\$$ a::nd $\$ \$$

PB. \& yes Jérôme \&\&

$\S$ yes Michel Calman-Lévy $\$ \$$ yes'

(96) P. mm vous aviez un programme pour la journée? pour la demi-journée [S. non a /] ou pour la semaine comment ça se passait

S. pou:::r e la semaine

P. pour la semaine?

S. oui

P. vous saviez par exemple lundi ? vous saviez ce que vous aviez à faire le mardi mercredi?

S. oui

P. comment vous le saviez

S. c'est lui qui c'e::st le monsieur qui nous a dit qui me qui m'a dit il faut faire ça [P. d'accord] le:: mardi et le mercredi

P. est-ce que c'était un stage rémunéré

S. non (MC, 82)

'P. mm did you have a program for the whole day / for half a day [S. no a /] or for the week how was that organized

S. fo:::r er the week

P. for the week

S. yes

P. did you know for instance on Monday? did you know what you had to do on Tuesday and Wednesday?

S. yes

P. how did you know

S. he the:: man told us told me you have to do this [P. okay] o::n Tuesday and Wednesday

P. did you receive an income from this work study

S. no'

3. One example appears to be a straightforward request for information about a B-event, which means that we would have expected it to be realized by SV:

(97) [discussion of a particular biography of General De Gaulle has come to an end] 
Ch. bon Jérôme Garcin je sais que vous \& ne l'avez pas lue mais vous avez lu plein \&む de biographies $\$$ de De Gaulle est-ce que: $\$ \$ \$$ quelle est la dernière que vous avez lue celle d'<Edwige> là de: la /

JG. \& mais je vais la lire maintenant parce que \&\&

FX. \$ on t'a excité est-ce que tu vas aller l'acheter? \$S (MP, 15)

'Ch. well Jérôme Garcin I know that you \& didn't read it but you've read plenty \&\& of biographies $\$$ of De Gaulle <est-ce que: $>\$ \$$ which is the last one you've read the one by $<$ Edwige $>$ abou:t the /

JG. \& oh but I'll read it now because \&\&

FX. $\$$ we've excited you are you going to go buy it? $\$ \S^{\prime}$

As a matter of fact, the question, which occurs in overlap with the chairperson's turn, remains unanswered, and when the larger context is considered, it appears to be but the last of an extended series of more or less facetious comments on the fact that the hearer JG has, by his own admission, not read the book in question because it "was too fat". Just prior to the interrogative in question, JG has declared his intention to read the book after all. FX's use of ESV here could then be analyzed as expressing a certain doubt, that is, she is emphatically wondering about whether JG's intention is sincere enough to actually make him go and buy the book.

4. The two remaining examples, which occur fairly close together in the same recording, actually do not go to completion because several speakers are competing for the floor:

(98) RL. mais le sept mai, soixante-cinq, votre journal e: rendait compte naturellement en / en / en e de façon élogieuse de la prise de position, du président de la république c'est-à-dire du général De Gaulle, qui: venait de DESapprouver, de façon absolument nette l'intervention américaine à: SaintDomingue e: je voulais le \& je / je XXX \& \&

PC. \& qui n'avait absolument aucun rapport \&\&

RL. je voulais je / je voulais le rappeler

PC. aucun rapport

RL. je voulais le rappeler

PC. ni dans les faits ni dans le droit

RL. parce qu'elle

PC. je me rappelle très bien \& de l'affaire \& \& de Saint-Domingue

RL. \& parce qu'elle \& \&

PC. même si je n'étais pas $\$$ directeur de la Nation $\$ \$$

HA. $\$$ est-ce que je peux $\$ \$$ 
RL. parce qu'elle se situait Exactement sur le même terrain

PC. absolument pas

RL. elle était de la même façon une violation du droit international, de la même façon elle était l'affirmation de la: prétention de l'impérialisme américain à diriger le mon:de et en particulier, à diriger tout le continent, américain

HA. bon est-ce que je peux \& dire XX \&

Ch. \& alors si vous voulez / non s'il vous plaît \&\&

RL. la première chose que je dirai(s) (VS1, 25-26)

'RL. but on May seventh, sixty-five, your newspaper e:r gave an / an / an er an obviously commendatory account of the position taken, by the president of France, that is General De Gaulle, who: had just quite unambiguously, DISapproved of the American intervention i:n the Dominican Republic e:r I wanted to \& I / I XXX \&\&

PC. \& which had absolutely nothing to do with this \&\&

RL. I wanted I / I wanted to remind you of that

PC. nothing to do with this

RL. I wanted to remind you of that

PC. neither from a factual nor from a legal point of view

RL. because it

PC. I quite clearly remember \& the Dominican Republic \&\& affair

RL. \& because it \&\&

PC. even though I wasn’t $\S$ the editor of la Nation $\S \S$

HA. $\$$ can I $\$ \$$

RL. because it was an instance of eXactly the same thing

PC. absolutely not

RL. it was as much a violation of international law, as much an affirmation of American imperialism's: pretensions to rule the wo:rld and in particular, to rule the whole American, continent

HA. all right now can I \& say XXX \&\&

Ch. \& now if you will / no please $\& \&$

RL. first I want to say'

It is probably safe to assume that the speaker's purpose in both instances is to request the chairperson's permission to take the floor. All three interrogative structures may be used for this purpose, but V-Cl and ESV will be the more polite structures because they explicitly wonder about whether permission will be granted. ESV being the more emphatic structure of the two, it seems 
particularly well suited to accomplish a speaker change in a strongly competitive situation such as this.

\section{Conclusion}

All in all, the hypotheses in sect. 4 appear to be confirmed by the data. The parameter of informational accessibility seems to be particularly important: Thus, $93,13 \%$ of the SV interrogatives express B-events, while $65,11 \%$ of the $\mathrm{V}-\mathrm{Cl}$ and ESV interrogatives put together express non-B-events. Participation structure seems to be the second-most important factor, followed by politeness and the particular emphatic quality of ESV.

Several of the constraints on interrogative forms which have been noted in previous research also seem to find a natural explanation within the present framework: If echo-questions and deductions from the interlocutor's discourse are generally constrained to the SV form, it is because they function as next turn repair initiators and candidate interpretations, respectively, and, as we have seen, both these utterance types can usually be classified as expressing B-events. Conversely, if self-addressed questions and rhetorical questions are generally constrained to $\mathrm{V}-\mathrm{Cl}$ or ESV, it is because these utterance types presuppose a complex participation structure.

The register considerations which are traditionally assumed to determine the choice of interrogative structure to quite a large extent can, I believe, be explained as well, without appealing to the notion of an on-going syntactic change confining $\mathrm{V}-\mathrm{Cl}$, in particular, to more formal, and hence more conservative, especially written, registers. According to Ashby (1977:41), there is in fact no indication that such a change is currently in progress in the spoken language. If $\mathrm{V}-\mathrm{Cl}$ is so little used in speech, while being quite common in writing, the reason may well be that many $\mathrm{V}$-Cl interrogatives in writing occur in printed expository prose, where no reaction is being actively solicited from the reader.

Conversely, in relatively informal interaction, questions about D-events, such as that in ex. (82) above, L'Europe est-elle en voie de dislocation? ('Is Europe falling apart?') will not usually be asked 'out of the blue'. If such matters are discussed, questions will typically be aimed at obtaining the addressee's personal opinion and they will therefore intuitively tend to be transformed, at least superficially, into B-events by the use of various kinds of epistemic and/or subjectivity markers, making SV the most likely structure, e.g. Tu crois que l'Europe est en voie de dislocation? ('Do you think that Europe is falling apart?'), 
L'Europe est en voie de dislocation, à ton avis ? ('Is Europe falling apart, in your opinion?'), etc. ${ }^{16}$

On a more general level, the results of this study appear to support the wellknown principle of semantic contrast, whereby complete synonymy is not allowed to persist in a language (e.g. Cruse 1986:270). This is of interest in so far as the applicability of that principle - which is largely, although not universally accepted with respect to lexical items - is still controversial when it comes to syntactic constructions.

The study also lends further support to the notion that interactional factors and the communicative function of utterances strongly influence the syntactic structures through which these utterances are realized in actual discourse. Moreover, it demonstrates that not only is a theory of discourse highly relevant to the study of syntax, but such a theory must be of a dynamic nature, in as much as the values of at least two of the parameters employed in this study, viz. the accessibility of information and the complexity of the participation structure, can change significantly from one utterance to the next.

Finally, this paper raises the issue of what exactly the relationship between interrogatives and questions is. Lyons (1977:754) defines interrogatives as "grammaticaliz[ing] the feature of doubt". If that is so, then $\mathrm{V}-\mathrm{Cl}$ and ESV should in some sense be the 'true' interrogative structures in modern French. On the other hand, it is SV which expresses the appeal to the interlocutor which is usually considered to be distinctive of 'real questions' as opposed to rhetorical ones, for instance. How to reconcile the two notions is an interesting problem, which will, however, not be pursued further in this paper.

\section{Notes}

* I would like to thank Hanne Korzen and Lene Schøsler for commenting on an earlier version of this paper. Clearly, they are not to be held responsible for any remaining shortcomings.

1. In the following, I will use term 'interrogative' when I am concerned with formal categories, whereas the term 'question' will be reserved for discussion of utterance functions. The difference will be discussed in more detail in sect. 5.2 below.

2. A non-standard form using the post-verbal particle $t i$ (originating in $\mathrm{V}$-Cl examples with a 3. person singular masculine subject, such as [1] above, cf. Foulet 1921, 269f) also exists, for instance:

(i) Pierre va-ti venir?

Lit.: Pierre will-ti come? 
Interrogatives of this type, however, will not be dealt with in the present paper, as they appear to be restricted to regional and/or popular speech. As a matter of fact, my corpora - which feature only educated Parisian speakers - do not contain a single example of such a form. Cf. Section 5.1 for a description of these corpora.

3. All authentic corpus examples used in this paper, as well as examples borrowed from other researchers, will be marked for their source. Any examples not so marked have been constructed by myself.

4. I wish to thank Professor Mary-Annick Morel of the Université de Paris III for allowing me access to the spoken language corpora collected by the UFR de linguistique française. Except in excerpts from radio broadcasts, all names occurring in examples from these corpora have been changed.

In examples from these recordings, the following transcription conventions have been observed:

$\& \ldots \& \&$ and $\$ \ldots \$ \$$ mark overlapping sequences;

, , , , , and - mark pauses of varying perceived duration;

/ marks an abrupt break in the speech stream;

(h) marks a hearable in-breath;

: marks the lengthening of a sound or syllable;

? marks rising intonation (Note that it does not mark interrogative status as such);

XXX marks a series of inaudible syllables;

$<\ldots>$ marks that the transcription is uncertain;

CAPITALS mark syllables or words spoken loudly;

${ }^{\circ} .{ }^{\circ}$ marks a sequence being spoken softly;

*...* marks a sequence being spoken quickly.

Underlining serves to highlight the particular structure(s) focused on in the main text.

5. Coveney (1996: ch. 6), who to my knowledge is the first scholar to systematically take this into account, uses the term 'categorical' about contexts which allow only one of the three structures, and the term 'semi-categorical' about contexts which allow two of the structures but exclude the third. However, although the constraints described by Coveney are undoubtedly real, several of them are not as absolute as his study might lead one to believe.

6. Two studies of interrogatives in French deal specifically with the speech of children, nineyear-olds in the case of Söll (1971), and three-to-five-year-old Swiss children in that of Sinclair \& Van Gessel (1990).

7. Coveney (1996: ch. 5) does in fact take a number of these factors into account when classifying his examples. Still, the results of my analysis differ from his in various ways.

8. Cf. note 2 above.

9. This account of the nature of rhetorical questions is in the spirit of Anscombre \& Ducrot's (op.cit.) analysis, but is not identical to it.

10. Complex NP V-Cl inversion is, in fact, a more recent construction that interrogative inversion as such: in Old French, even subject NPs would occur postverbally in interrogatives, and the 'complex' construction, which originates in a dislocation construction, does not fully replace the original V-S inversion pattern until the 16th century (Foulet 1921:250) 
11. The underlying assertoric nature of SV interrogatives seems to be supported by the fact that whereas the subjunctive mood is frequently found in the complement clause of a $\mathrm{V}-\mathrm{Cl}$ interrogative whose main predicate is a verb of saying or a verb of opinion, and may be found in the complement clause of an ESV interrogative, it is apparently non-existent in the SV construction (cf. Nordahl 1969:214):

(i) Crois-tu qu'il l'ait fait?

(ii) Est-ce que tu crois qu'il l'ait fait?

(iii) * Tu crois qu'il l'ait fait?

'Do you believe that he did (subj.) it?'

12. The \# sign indicates pragmatic oddity.

13. Clearly, (19)-(19') and (20)-(20') resemble rhetorical questions like (12) above, but in these examples, $p$ ? does not implicate $\sim p$, but rather 'It is not certain that p', i.e. the speaker cannot be said to know the answer at the time of utterance.

14. As noted above, negated ESV interrogatives are actually quite rare, although not nonexistent.

15. This question also takes the form of an ESV interrogative, but has been classified as expressing a B-event because of its 2 nd person subject and autocognitive verb.

16. As a matter of fact, intuitively, the simple SV interrogative, L'Europe est en voie de dislocation ?, would most likely not be understood as asking for the hearer's opinion on a matter of controversy, but rather as an information question directed to an addressee assumed to know something the speaker didn't.

\section{References}

Anscombre, Jean-Claude; and Ducrot, Oswald. 1983. L'argumentation dans la langue. Liège: Mardaga.

Ashby, William J. 1977. "Interrogative forms in Parisian French.” Semasia 4: 35-52.

Behnstedt, Peter. 1973. Viens-tu ? Est-ce que tu viens? Tu viens? Formen und Strukturen des direkten Fragesatzes im Französischen. Tübingen: Günter Narr.

Brown, Penelope; and Levinson, Stephen C. 1987. Politeness. Some universals of language usage. Cambridge: Cambridge University Press.

Coveney, Aidan. 1996. Variability in spoken French. A sociolinguistic study of interrogation and negation. Exeter: Elm Bank Publications.

Cruse, D. A. 1986. Lexical semantics. Cambridge: Cambridge University Press.

Damourette, Jacques; and Pichon, Edouard. 1911-1934. Des mots à la pensée. Essai de grammaire de la langue française, vol. IV. Paris: D’Artrey.

Ducrot, Oswald. 1984. Le dire et le dit. Paris: Editions de Minuit.

Fillmore, Charles; Kay, Paul; and O'Connor, Mary Catherine. 1988. "Regularity and idiomaticity in grammatical constructions. The case of 'let alone." Language 64(3): 501-538.

Fontaney, Louise. 1991. “A la lumière de l'intonation.” In: Kerbrat-Orecchioni, Catherine (ed.), La question, 113-161. Lyons: Presses universitaires de Lyon. 
Foulet, Lucien. 1921. “Comment ont évolué les formes de l'interrogation.” Romania XLVII: 243-348.

Fromaigeat, E. 1938. "Les formes de l'interrogation en français moderne : leur emploi, leurs significations et leur valeur stylistique." Vox Romanica 3: 1-47.

Goffman, Erving. 1967. "On face-work.” In his: Interaction ritual, 5-45. Chicago: Aldine. Goffman, Erving. 1981. "Footing.” In his: Forms of talk, 124-159. Oxford: Blackwell. Goody, Esther N. 1978. “Towards a theory of questions.” In: Goody, Esther N. (ed.), Questions and politeness, 17-43. Cambridge: Cambridge University Press.

Gordon, David; and Lakoff, George. 1975. “Conversational postulates.” In: Cole, Peter; and Morgan, Jerry L., (eds.), Syntax and semantics, vol. 3, 83-106. New York: Academic Press.

Grevisse, Maurice. 1988. Le bon usage. 12th ed. revised by André Goosse. Paris: Duculot. Grice, H. Paul. 1975. "Logic and conversation.” In: Cole, Peter; and Morgan, Jerry L. (eds.), Syntax and semantics, vol. 3, 41-58. New York: Academic Press.

Hansen, Maj-Britt Mosegaard. 1998a. The function of discourse particles. A study with special reference to spoken standard French. Amsterdam: John Benjamins.

Hansen, Maj-Britt Mosegaard. 1998b. "La grammaticalisation de l'interaction, ou, Pour une approche polysémique de l'adverbe 'bien'.” Revue de Sémantique et Pragmatique 4: 111-138.

Heritage, John. 1984. Garfinkel and ethnomethodology. Cambridge: Polity Press.

Hopper, Paul J. 1991. “On some principles of grammaticization.” In: Traugott, Elizabeth Closs; and Heine, Bernd (eds.), Approaches to grammaticalization, vol.1, 17-35. Amsterdam: John Benjamins.

Kerbrat-Orecchioni, Catherine. 1991. "L'acte de question et l'acte d'assertion: opposition discrète ou continuum ?” In: Kerbrat-Orecchioni, Catherine (ed.), La question, 87-111. Lyons: Presses universitaires de Lyon.

Labov, William; and Fanshel, David. 1977. Therapeutic discourse. New York: Academic Press.

Langacker, Ronald W. 1987. Foundations of Cognitive Grammar, vol. 1. Stanford, CA: Stanford University Press.

Levinson, Stephen C. 1983. Pragmatics. Cambridge: Cambridge University Press.

Lyons, John. 1977. Semantics, vols. 1-2. Cambridge: Cambridge University Press.

Nordahl, Helge. 1969. Les systèmes du subjonctif corrélatif. Bergen: Universitetsforlaget.

Pohl, Jacques. 1965. "Observations sur les formes d'interrogation dans la langue parlée et dans la langue écrite non littéraire.” In: Straha, Georges (ed.), Linguistique et philologie romanes. Xe Congrès international de linguistiques et philologie romanes, t. II, 501-513. Paris: Klincksieck.

Rémi-Giraud, Sylvianne. 1991. "Question et assertion. De la morpho-syntaxe à la pragmatique.” In: Kerbrat-Orecchioni, Catherine (ed.), La question, 39-62. Lyons: Presses universitaires de Lyon.

Roulet, Eddy; Auchlin, Antoine; Moeschler, Jacques; Rubattel, Christian; and Schelling, Marianne. $1987^{2}$. L'articulation du discours en français contemporain. Bern: Peter Lang. 
Sacks, Harvey; and Schegloff, Emanuel A. 1979. "Two preferences in the organization of reference to persons in conversation and their interaction.” In: Psathas, George (ed.), Everyday language: Studies in ethnomethodology, 15-21. New York: Irvington.

Schegloff, Emanuel A.; Jefferson, Gail; and Sacks, Harvey. 1977. "The preference for selfcorrection in the organization of repair in conversation." Language 53(2): 361-382.

Sinclair, Anne; and Van Gessel, Ruth. 1990. "The form and function of questions in children's conversations.” Journal of Pragmatics 14: 923-944.

Söll, Ludwig. 1971. "Der neufranzösische direkte Fragesatz in einem Corpus der Kindersprache.” In: Coseriu, Eugenio; and Stempel, Wolf-Dieter (eds.), Sprache und Geschichte, 493-506. Munich: Wilhelm Fink.

Stenström, Anna-Brita. 1984. Questions and responses in English conversation. Lund:

C.W.K. Gleerup.

Terry, Robert M. 1970. Contemporary French interrogative structures. Montreal: Editions Cosmos.

\section{Appendix}

Table 1. Distribution of interrogative forms in the individual recordings
A. Name of recording
B. Length of recording in minutes
C. Length of recording as a percentage of the total length of the data base
D. No. of closed interrogatives in recording
E. Percentage of interrogatives in recording out of total no. of interrogatives in the data base
F. No. of $\mathrm{V}-\mathrm{Cl}$ interrogatives in recording
G. Percentage of $\mathrm{V}-\mathrm{Cl}$ out of total no. of interrogatives in recording
$\mathrm{H}$. Percentage of $\mathrm{V}-\mathrm{Cl}$ in recording out of total no. of $\mathrm{V}-\mathrm{Cl}$ in data base
I. No. of ESV interrogatives
J. Percentage of ESV out of total no. of interrogatives in recording
K. Percentage of ESV in recording out of total no. of ESV in data base
L. No. of SV interrogatives in recording
M. Percentage of SV out of total no. of interrogatives in recording
N. Percentage of SV in recording out of total no. of SV in data base 


\begin{tabular}{lllllllll}
\hline A. & CT & CV & VE & AF & VS1 & VS2 & MP & MC \\
\hline B. & $20 \mathrm{~m}$. & $19 \mathrm{~m}$. & $34 \mathrm{~m}$. & $45 \mathrm{~m}$. & $45 \mathrm{~m}$. & $45 \mathrm{~m}$. & $50 \mathrm{~m}$. & $15 \mathrm{~m}$. \\
C. & $7,32 \%$ & $6,95 \%$ & $12,34 \%$ & $16,48 \%$ & $16,48 \%$ & $16,48 \%$ & $18,3 \%$ & $5,49 \%$ \\
D. & 52 & 27 & 22 & 51 & 16 & 9 & 32 & 38 \\
E. & $21,05 \%$ & $10,93 \%$ & $8,9 \%$ & $20,64 \%$ & $6,47 \%$ & $3,64 \%$ & $12,95 \%$ & $15,38 \%$ \\
F. & 1 & - & - & - & 1 & 5 & - & - \\
G. & $1,92 \%$ & - & - & - & $6,25 \%$ & $55,55 \%$ & - & - \\
H. & $14,28 \%$ & - & - & - & $14,28 \%$ & $71,42 \%$ & - & - \\
I. & 2 & 5 & 5 & 4 & 9 & 1 & 6 & 4 \\
J. & $3,84 \%$ & $18,51 \%$ & $22,72 \%$ & $7,84 \%$ & $56,55 \%$ & $11,11 \%$ & $18,75 \%$ & $10,52 \%$ \\
K. & $5,55 \%$ & $13,88 \%$ & $13,88 \%$ & $11,11 \%$ & $25 \%$ & $2,77 \%$ & $16,66 \%$ & $11,11 \%$ \\
L. & 49 & 22 & 17 & 47 & 6 & 3 & 26 & 34 \\
M. & $94,23 \%$ & $81,48 \%$ & $77,27 \%$ & $92,15 \%$ & $37,5 \%$ & $33,33 \%$ & $81,25 \%$ & $89,47 \%$ \\
N. & $24,25 \%$ & $10,89 \%$ & $8,41 \%$ & $23,26 \%$ & $2,97 \%$ & $1,48 \%$ & $12,87 \%$ & $16,83 \%$ \\
\hline
\end{tabular}

\section{Author's address}

Maj-Britt Mosegaard Hansen, Ph.D.

Associate Professor of French linguistics

Department of Romance Studies

University of Copenhagen

Njalsgade 80

DK-2300 Copenhagen S

Denmark

Email: maj@hum.ku.dk 